$1-1-1975$

\title{
An analysis of the ratios of assessments to sales values for real estate in West Virginia
}

\author{
Alan J. Levy \\ Dale Colyer
}

Follow this and additional works at: https://researchrepository.wvu.edu/ wv_agricultural_and_forestry_experiment_station_bulletins

\section{Digital Commons Citation}

Levy, Alan J. and Colyer, Dale, "An analysis of the ratios of assessments to sales values for real estate in West Virginia" (1975). West Virginia Agricultural and Forestry Experiment Station Bulletins. 640.

https://researchrepository.wvu.edu/wv_agricultural_and_forestry_experiment_station_bulletins/547 @ WVU. It has been accepted for inclusion in West Virginia Agricultural and Forestry Experiment Station Bulletins by an authorized administrator of The Research Repository @ WVU. For more information, please contact ian.harmon@mail.wvu.edu. 


\section{An Analysis of the}

Ratios of Assessments to Sales Values for Real Estate in West Virginia

Bulletin 640
August 1975
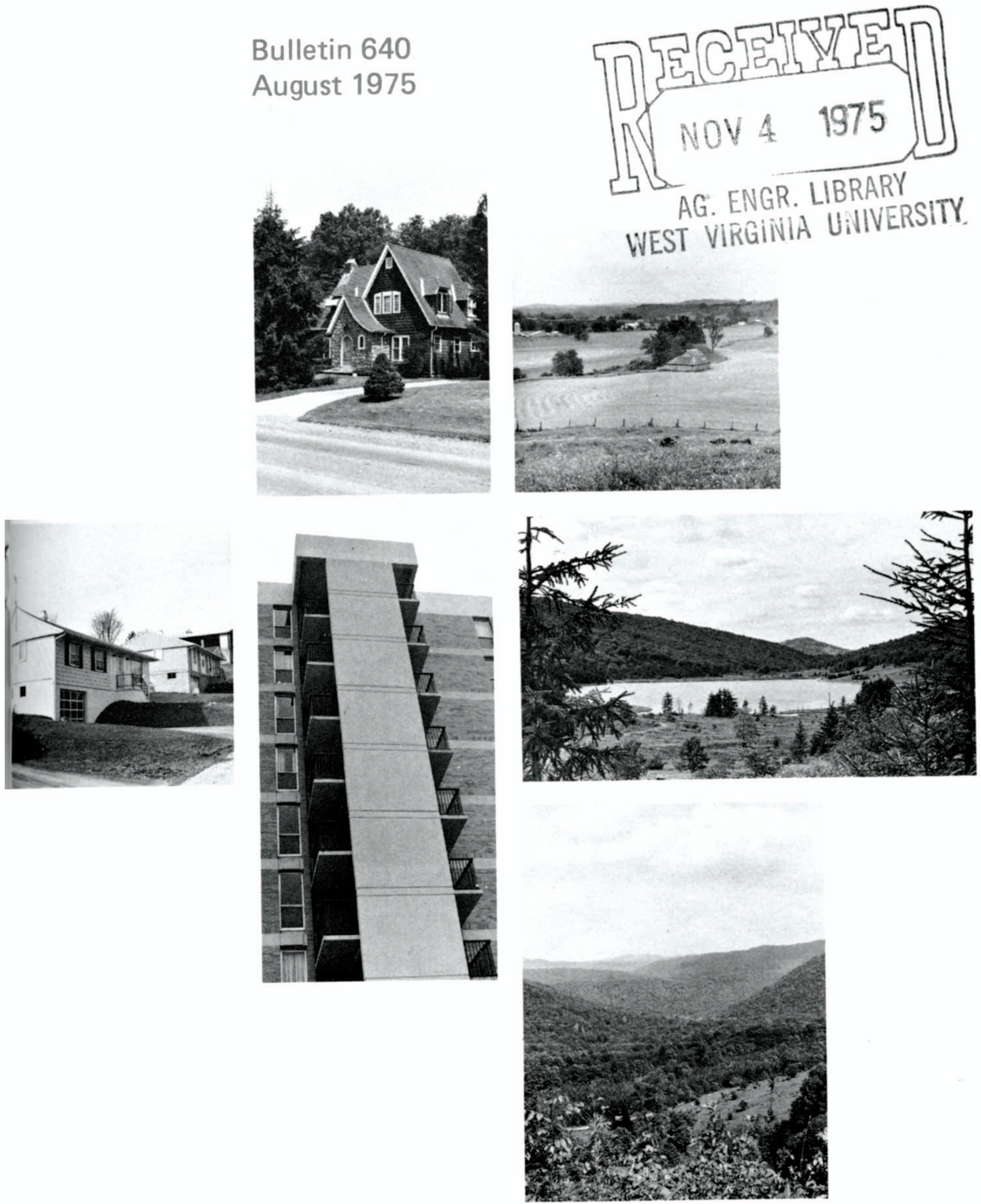

West Virginia Universitv Aaricultural Experiment Station 


\section{THE AUTHORS}

At the time of this study, Alan J. Levy was a Graduate Assistant in the Division of Resource Management; Dale Colyer is Agricultural Economist.

West Virginia University Agricultural Experiment Station College of Agriculture and Forestry

Dale W. Zinn, Director

Morgantown 


\section{SUMMARY AND CONCLUSIONS}

The information for this study was obtained from reports completed by the individual county assessors and sent to the State Tax Commissioner. The Tax Commissioner's Office supplied the reports to the West Virginia University Agricultural Experiment Station. Data were included from 51 of 55 counties for portions of 1971-72, but information from one county was incomplete and could not be used. All sales were to have been examined by the assessors for non-market influences to assure inclusion of only bona fide market transactions. There was a total of 7,313 such transactions covered by the reports sent to the Experiment Station for the period of the study.

The assessment to consideration ratio represents the relationship between the market value of the property and its assessed value. In this study the assessment ratio was used to evaluate assessment practices, particularly to determine if there were inequities in assessments. The average assessment ratio for the state was 0.3357 . The majority of the counties had average ratios between 0.20 and 0.40 and, thus, were centered around the state average, but there was considerable variation in the average ratios both among and within the 50 counties from which data were received.

The results of the study were compared with those of two previous similar studies for West Virginia. The Armentrout-Haygood study for 1950 included 48 counties and used the assessed valuation for the year following the sale. There were 23,280 sales with an average ratio of 0.3137 . The Colyer-Templeton study for 1968-69 included data on nearly 32,000 transfers from July 1, 1968, through June 30, 1969, for all 55 counties. Assessment to consideration ratios were determined on both a pre-sale and a post-sale basis. The average pre-sale ratio was 0.402 while the average post-sale ratio had increased to 0.456 .

All three studies found that properties of low value tended to be assessed at relatively higher levels than the properties of higher values. Also, that unimproved properties tended to be assessed at much lower values relative to their sales prices than other types of properties. The latter two studies concluded that larger acreages were assessed relatively lower than other properties, indicating that farms probably were assessed lower - a finding contrary to the 1950 records. All three studies also found that, despite the tendencies previously noted, there were large variations in assessments within all categories studied as well as within and between counties.

The primary conclusion that can be drawn from this study is that there are inequities in property tax assessments, both within and between counties. This inequity is due, in part, to poor property tax administration. One source of problems has been the lack of periodic reassessments. Another problem is that many assessors reassess properties that are sold while similar properties that have not changed owners are assessed at values that existed in the base period. A considerable amount of the variation, however, appears to be caused by systematically preferential treatment of some kinds of properties, such as unimproved lots and farms. 
This study also has shown that assessment and appraisal practices do not reflect reality. Appraisals are supposed to represent the market value of the property and assessment values are usually 50 per cent of the appraised value. The state's average assessment-sales value ratio was 0.3357 in 1971-72, with the various county assessment averages fluctuating around this figure. This indicates that appraised values for tax purposes are not being increased when market values increase.

Amount of consideration, acreage, location, improvements, zoning, tax class, and land use are all factors that influence the assessment ratio. Two of the most striking factors in this study were the tendency for assessments to decline in relative terms as values increased and for unimproved properties to be assessed at much lower ratio relative to value than improved properties. The first practice probably gives a tax break to those who are financially worth more and thus contributes to the regressivity of the property tax. The second procedure is probably beneficial to developers and speculators since it results in a relatively inexpensive land holding operation. Since West Virginia property taxes are already low, land speculation becomes a relatively low-cost procedure.

Finally, it should be noted that there was a great deal of variability between the distributions of the assessment-sales value ratios between and within the various counties as shown both in the current and previous studies. The greatest causes in variability in these studies appear to result from the practices of the individual assessors, his assistants, and perhaps the county court through its review procedure.

Inequities imply different treatments of individual taxpayers, which technically are unconstitutional as well as unfair. This should be expected to cause dissatisfaction with the property tax assessment system. That there does not appear to be as much dissatisfaction in West Virginia as in some states may be due to the relatively low level of property taxes because of the constitutional limit on tax rates. 


\title{
An Analysis of the Ratios Of Assessments to Sales Values For Real Estate in West Virginia
}

\author{
Alan J. Levy and Dale Colyer
}

Property taxation begins with the determination of the value of the properties to be taxed. The amount of taxes to be paid is a function of the tax rate and assessed value, and since in West Virginia the tax rate is limited by provisions of the State Constitution, the level of assessment is the major variable in amounts paid. Furthermore, the same rate applies to all properties of a given class in any particular taxing jurisdiction so that concerns with inequity between property taxpayers tend to focus on assessment levels and on the individuals who determine these levels: the county assessor, commissioners of the county court who act as a review board, and, to some extent, the State Tax Commissioner who has the power to reappraise property values for tax purposes. The assessor generally is the key figure in the process since he or she determines the value put into the tax books, subject of course, to challenge and review.

A common complaint in many areas has been that the property tax is not equitably administered. ${ }^{1}$ One method used to evaluate assessment practices is assessment-sales value ratio studies. For these studies, the assessed value of a property that has been transferred is divided by the sales value. Comparisons between the ratios for different properties can then be used to help evaluate the assessment process. Some caution is called for in such studies since many factors can affect the amount paid for a piece of property and such prices are not always reflections of the true market value. If sufficiently large numbers of transfers are examined, however, information can be obtained on which to base qualified judgments about the assessment process.

\section{OBJECTIVES}

The overall objective of this study was to evaluate the manner in which real property is being assessed and taxed and to determine if inequities exist between the value of property and its present assessments and taxes. Specific objectives were: (1) To review current assessments; (2) To determine if there are inequities and if there are; (3) To indicate the factors that affect property assessments; and (4) To compare the current situation with those shown in previous studies.

1See, for instance, U. S. Senate, Property Taxes, Subcommittee on Intergovernmental Jperations, G.P.O., Washington, 1973. 


\section{DATA AND PROCEDURES}

The information for this study was obtained from reports of real estate transfers that the county assessors in West Virginia must send to the State Tax Commissioner's Office in Charleston. The data used were provided to the Division of Resource Management by the Office of the Commissioner. Five of the 55 counties had either unusable information, had not provided information, or information was not included in the data for some other reason. A total of 7,313 bona fide transactions were included for the 1971-72 study period. The information for several counties contained only a small number of sales and probably was not complete.

The report form used has four sections. The first section shows general information, such as the county and district, the date of the transaction, the grantor and the grantee, and the acreages involved in the transactions. The second section contains most of the pertinent information used for this study: the value information including the state appraisal values, county assessed values, the sales price, and the value of personal property included in the sale. The assessment-sales value ratio represents the relationship between the market value of a property and its assessed value, i.e., it is the assessment divided by the consideration. The third section is involved with the property's characteristics, including zoning, present land use, best land use, tax class, location, and the presence of improvements. The final section is for verification by the assessor.

The procedure followed in the review of assessment practices was to examine the laws concerning assessment and land classification in West Virginia. Included were the assessor's qualifications, duties, and problems faced in order to complete the job. To make the interpretation more meaningful and understandable, several basic concepts such as property tax assessments, appraisals, and assessment ratio are defined.

In the examination of assessment practices, descriptive statistics from the sales ratio data are used. The assessment-sales value ratios were computed by dividing the assessed value by the reported sales value minus the value of any personal property included in the sale. Average ratios for the state, individual counties, and other sub-categories were computed by dividing the average assessment by the average sales value (consideration) for the classification being used. The average ratios then are weighted by the values involved rather than being simple arithmetic means of the computed ratios for the individual parcels of land being studied.

\section{SOME BASIC CONCEPTS}

The first concept to be defined for this analysis is that of the property tax. It is an annual levy by a governmental body on real or personal property. Land and its improvements account for the largest share of property taxes actually levied and paid in West Virginia. 
Related concepts are assessment and appraised values. The appraised value is the value placed on the property, which is supposed to represent the true market value but which usually is the valuation at some past time. The State Tax Commissioner has the authority to appraise properties for tax purposes in West Virginia, but the power also has been delegated to the county assessors. The Tax Commissioner, however, retains the basic authority, but the state office has too small a staff of appraisers to adequately carry out the function. The delegation of power was authorized through legislative action in 1958 (Chapter 18, Article 9A).

The assessment is the value placed on the property for tax purposes. It is determined by the county assessor and his deputies and is entered into the land books and used to compute the taxes levied by multiplying the assessed value by the appropriate tax rate. Within a county the assessed value generally is a standard percentage of the appraised value, most frequently 50 per cent due to a requirement for school taxes that the average assessment for a county be at least half the appraisal values.

The appraisal and assessment processes begin with the determination of the "true and actual value" of the property. There are three basic approaches to the property valuation process: cost, market, and income. For assessment purposes the market valuation approach is used. Cost can be measured as original cost, replacement cost, reproduction cost, substitution cost, cost less depreciation, cost plus appreciation, or any one of several other variations. The cost method is concerned with establishing a value by studying the cash outlay required to purchase the property. The income approach is usually limited to commercial and farm property used to generate a profit, or for land purchased for speculation. Under this approach, present value of the property, which is the discounted flow of future earnings that the property can be expected to produce, is determined. Market valuation is the price at which the property would change hands, given a knowledgable and willing buyer and seller. Determining this is not always easy because the land market is very imperfect since frequently there is an imbalance of buyers and sellers as well as a general lack of knowledge regarding the land market. Land markets can be influenced by many short-run as well as long-run factors, causing a deviation from "real" values. Real values in this case would be values that one would find under normal or typical conditions, i.e. the market equilibrium price.

\section{THE TAX LAWS}

The Constitution of West Virginia is the basis under which the property tax laws are set up. The Constitution allows for four classes of property, according to use, in the following manner:

...taxation shall be equal and uniform throughout the State, and all property... shall be taxed in proportion to its value to be ascertained as directed by law. No one species of property from which a tax may be 
collected shall be taxed higher than any other species of property of equal value, except that the aggregate of taxes assessed in any one year upon personal property employed exclusively in agriculture, including horticulture and grazing, products of agriculture as above defined, including livestock, while owned by the producer and money, notes, bonds, bills, and accounts receivable, stocks and other similar intangible personal property shall not exceed fifty cents on each one hundred dollars of value theron and upon all property owned, used and occupied by the owner thereof exclusively for residential purposes and upon farms occupied by their owners or bona-fide tenants one dollar; and upon all other property situated outside of municipalities, one dollar and fifty cents; and upon all other such property situated within municipalities, two dollars.

Class I property is personal property. This study is concerned with real property and not personal property. Class II property is real property used for residential purposes and farmland that is occupied and cultivated by owners or bona-fide tenants. Class III is all property exclusive of Class I and Class II, located outside of municipalities. Class IV is all property exclusive of Class I and Class II, located within municipalities. All four classes of property are taxed on an ad valorem basis, which means that the tax is based on the dollar value of the item.

A state-wide reappraisal program under Senate Bill 34 was started in West Virginia during 1958 and completed in 1967. The program was undertaken to obtain equalization of assessed property values in the state, and involved the following four steps:

1. The microfilming of all county records pertaining to property transfers;

2. The production of aerial photographs from which tax maps were drawn;

3. The actual appraisal-determination of the true and actual value of the property; and

4. The checking of the work performed in the first steps for accuracy by employees of the Office of State Tax Commissioner and the certification of the reappraisal to the county court and the county assessor.

\section{ASSESSMENT PROCEDURES IN WEST VIRGINIA}

West Virginia is divided into assessment districts where each county is a district. Each assessment district elects the assessor for a four-year term. The main qualification for the county assessor is that he or she must be a resident of the county at election time and must also have the capacity to carry out the responsibilities associated with the office. At the state level the Tax Commissioner has the power to appraise properties for tax purposes, but generally does not review the assessments except to determine that the average assessment for a county is at least 50 per cent of the appraisal value.

The assessor has three basic responsibilities; they are to (1) identify all taxable property in the jurisdiction, (2) estimate the value of property for 
assessment purposes, and (3) prepare a roll annually listing all such property as required by law. The assessor is assumed to update the appraisals and assessments each year, but, realistically, this is a virtual impossibility. The major obstacle to such a procedure is an insufficient amount of resources to provide for an adequately trained or sufficiently manned staff who can make frequent and careful reappraisals of property values on location.

The system of compensation for assessors is based on the assessed valuations of property. In Chapter 21 in The Acts of the Legislature of West Virginia, 1972, it is stated that, ". . .counties are classified on the basis of assessed valuations for the purpose of determining compensation of. . elected county officials." The schedule for determining compensation is shown in Table 1.

Some additional duties of the county assessor are stated in the West Virginia Code (11-2-5A):

1. He shall annually complete a sales ratio analysis in a manner prescribed by the state tax commissioner.

2. He shall present to the tax commissioner a list of real property transfers of the prior assessment year by December 1st annually.

3. He shall on or before December 1st of each year supply a list of new construction and improvements exceeding $\$ 1,000$ of the previous assessment year on forms prescribed by the state tax commissioner.

4. He shall on or before December 1st of each year supply a list of new businesses added to the assessment rolls and businesses that have discontinued operations in the previous assessment year and have been removed from the assessment rolls.

5. He shall provide assistance to the tax commissioner to disseminate information with respect to the taxation, classification, and valuation of the non-utility and public utility property to the end that all property shall be more equally and uniformly assessed throughout the state.

6. He shall annually assist the tax commissioner in determining the current use of such real property in his county as the tax commissioner may require to accomplish a uniform appraisal and assessment of real property.

\section{TABLE 1. Property Assessment Classes and Compensation of County Officials}

\begin{tabular}{lccr}
\hline \hline Class & $\begin{array}{c}\text { Minimum Assessed } \\
\text { Value of Property }\end{array}$ & $\begin{array}{c}\text { Maximum Assessed } \\
\text { Value of Property }\end{array}$ & Compensation \\
\hline Class I & $\$ 600,000,000.00$ & No limit & $\$ 12,000.00$ \\
Class II & $450,000,000.00$ & $\$ 599,999,999.00$ & $8,400.00$ \\
Class III & $200,000,000.00$ & $499,999,999.00$ & $12,000.00$ \\
Class IV & $100,000,000.00$ & $199,999,999.00$ & $10,000.00$ \\
Class V & $50,000,000.00$ & $99,999,999.00$ & $9,000.00$ \\
Class VI & $15,000,000.00$ & $49,999,999.00$ & $6,900.00$ \\
Class VII & 0.00 & $14,999,999.00$ & $3,600.00$ \\
\hline
\end{tabular}


The assessor must also certify the completion of his assessment to the county court and the tax commissioner. When he makes the assessment he makes at least three copies of the land books and two copies of the personal property books - one copy goes to the sheriff, one to the clerk of the county court, and one copy to the state auditor.

\section{ASSESSMENT TO CONSIDERATION RATIOS}

The assessment to consideration ratio represents the relationship between the market value of the property and its assessed value. ${ }^{2}$ Since, under the State Constitution, taxes are to be "proportional to value," an analysis of assessment to consideration ratios can be used to indicate how well appraisals and assessments are related to current market values. A state average less than 0.5 tends to indicate that market values are changing more rapidly than assessments. Variations in the average assessment to consideration ratios between counties would be an indication of differences in rates of change in values and assessments between counties. This, however, would not per se be an indication of relative tax burdens of individual property owners within a county since property taxes are nearly completely county and municipal levies. Variations between individual properties within a county, however, would be an indication that relative tax burdens are not closely related to value and, hence, that inequities might exist. It is important to note that the assessments used for this study were done prior to, not after, the sale and that this might make a difference since values of different properties change at different rates.

In the following sections, average state and county ratios and their frequency distributions will be examined and then the differences in ratios due to specific factors which might affect them will be analyzed.

\section{Average Ratios}

The average assessment ratios for the state and the individual counties are shown in Table 2. The average for the 50 counties was 0.3357 with 7,216 observations. Thus, instead of one-half, as might be expected, the average assessment is about one-third of the market value. The average county assessment ratios varied from a low of 0.1032 to 0.5308 . The lowest average in the state was for Pendleton County. Two other counties had ratios under $0.2-$ Hampshire County with 0.1636 , and Hardy County at 0.1980 . At the other end of the scale, the highest ratio was in Harrison County, but there were only nine sales reported and the ratio may not have been representative. The next highest ratio was in Webster County with a ratio of 0.4246 and 91 observations.

2The assessment to consideration (or sales value) ratios are not necessarily related to the percentages that assessed values are of appraised values. The appraised values generally were determined during the reappraisal program between 1958 and 1967 whereas the consideration used is the amount a parcel sold for during the period of this study. 
TABLE 2. Average County Assessment to Sales Value Ratios, 1971-72

\begin{tabular}{|c|c|c|}
\hline County & Average Ratio & No. of Observations \\
\hline Barbour & 0.3500 & 74 \\
\hline Berkeley & 0.3239 & 106 \\
\hline Boone & 0.2979 & 99 \\
\hline Braxton & 0.3506 & 96 \\
\hline Brooke & 0.3806 & 197 \\
\hline Cabell & 0.3602 & 775 \\
\hline Calhoun & 0.3339 & 46 \\
\hline Clay & 0.4134 & 72 \\
\hline Doddridge & 0.2504 & 92 \\
\hline Fayette & 0.2929 & 99 \\
\hline Gilmer & 0.2592 & 140 \\
\hline Grant & 0.2426 & 69 \\
\hline Hampshire & 0.1636 & 25 \\
\hline Hancock & 0.3911 & 163 \\
\hline Hardy & 0.1980 & 74 \\
\hline Harrison & 0.5308 & 9 \\
\hline Jackson & 0.3637 & 142 \\
\hline Jefferson & 0.2536 & 102 \\
\hline Logan & 0.2482 & 42 \\
\hline McDowell & 0.3938 & 29 \\
\hline Marion & 0.3357 & 339 \\
\hline Marshall & 0.3316 & 176 \\
\hline Mason & 0.3243 & 8 \\
\hline Mercer & 0.3220 & 181 \\
\hline Mineral & 0.3335 & 158 \\
\hline Mingo & 0.2530 & 118 \\
\hline Monongalia & 0.3047 & 371 \\
\hline Monroe & 0.2370 & 55 \\
\hline Morgan & 0.3231 & 70 \\
\hline Nicholas & 0.3520 & 98 \\
\hline Ohio & 0.4101 & 390 \\
\hline Pendleton & 0.1032 & 35 \\
\hline Pleasants & 0.3273 & 28 \\
\hline Pocahontas & 0.2889 & 26 \\
\hline Preston & 0.2406 & 138 \\
\hline Putnam & 0.2839 & 199 \\
\hline Raleigh & 0.2987 & 86 \\
\hline Randolph & 0.3409 & 50 \\
\hline Ritchie & 0.3358 & 142 \\
\hline Roane & 0.3589 & 157 \\
\hline Summers & 0.3048 & 260 \\
\hline Taylor & 0.4179 & 68 \\
\hline Tucker & 0.2631 & 39 \\
\hline Tyler & 0.3033 & 20 \\
\hline Upshur & 0.3205 & 147 \\
\hline Wayne & 0.2648 & 91 \\
\hline Webster & 0.4246 & 91 \\
\hline Wetzel & 0.3750 & 157 \\
\hline Wood & 0.3579 & 897 \\
\hline Wyoming & 0.2835 & 170 \\
\hline 50 Counties & 0.3357 & 7,216 \\
\hline
\end{tabular}




\section{TABLE 3. Number of Counties Within Specific Ranges of Assessment to Sales Ratios}

$0.10-0.149$

0.15-0.199

$0.20-0.249$

$0.25-0.299$

$0.30-0.349$

$0.35-0.399$

$0.40-0.449$

$0.45-0.499$

A clearer picture of the distribution of the ratios is given in Table 3, which shows the number of counties with average ratios in each five percentile group from 0.1 to over 0.5 . The majority of the county average ratios were between 0.25 and 0.4 and, thus, were centered around the state average of 0.3357 , but there was considerable variation in the average ratios among the 50 counties from which data were received.

\section{Frequency Distributions}

An important procedure for evaluating the equity of assessments is a frequency distribution of the ratios. The frequency distribution shows how the assessment ratios are spread out or concentrated. For this study the frequency distribution was divided into 11 assessment to consideration ratio classes: 0.01-0.09; 0.1-0.19; 0.2-0.29; 0.3-0.39; 0.4-0.49; 0.5-0.59; 0.6-0.69; 0.7-0.79; $0.8-0.89 ; 0.9-0.99$; and over 0.99 . The percentage of observations falling within a particular range, rather than the number of observations, is given in Table 4 so that inter-county comparisons will be facilitated.

For the state, 66.94 per cent of the assessment ratios were less than 0.4 and in 45 out of 50 counties at least 50 per cent of the assessment ratios were 0.4 or less. For the state some 17.16 per cent of the assessment ratios were 0.5 or higher while in 29 out of 50 counties less than 20 per cent of the sales had assessment ratios of 0.5 or higher. Nearly two thirds of the sales were assessed at ratios of between 0.2 and 0.49 . The most important observation is that considerable variation exists between the counties in the state, as well as a large amount of variation in the ratios within each county.

\section{Assessment Ratios by Consideration}

For an evaluation of the effect of consideration on the assessment ratios, sales values were grouped into the following five classes: $\$ 1-999 ; \$ 1,000-9,999$; $\$ 10,000-24,999 ; \$ 25,000-49,999$; and $\$ 50,000$ plus. These classes represent 
dollar values associated with the sale. The most sales occurred in the range of $\$ 1,000$ to $\$ 9,999$ in consideration (Table 5). The class with the fewest sales was the $\$ 50,000$ plus group. The average ratios for the state tended to decline as consideration increased for sales of under $\$ 25,000$ but increased slightly for the typical higher valued transfers.

Twelve of the 50 counties had average ratios that decreased constantly, while in most of the rest of the cases the ratios followed the pattern for the state which was to decrease at first and then to increase slightly in the higher consideration classes.

Apparently, the larger the consideration, up to a certain level, the smaller the assessment ratio tends to be (Table 5). The amount of consideration affects the assessment ratio, with the more valuable properties frequently being assessed at a lower percentage of market value than the less valuable properties. Quite possibly, the higher priced properties are the ones whose values have increased more rapidly and, since there is no periodic or systematic reappraisal of property in West Virginia, the results may be, in part, unintentional rather than a preferential treatment of higher valued properties. Since only pre-transfer assessments were used, this cannot be conclusively determined. However, the data from related studies reported later tend to confirm the conclusion that higher valued properties are assessed at relatively lower rates than lower valued properties.

\section{Assessment Ratios by Acres}

To study the effects of acreage on the assessment ratios, the sales were grouped by acres into the following five classes: $0.1-0.9 ; 1-4.9 ; 5-24.9 ; 25-99.9$; and 100 plus acres. The average ratios for the state in these five classes decreased steadily as acreage size increased, from 0.3235 for the $0.1-0.9$ acres to 0.1852 for the 100 plus acreage class (Table 6). There were 28 counties where the ratio decreased and then increased for one or more of the larger acreage classes. However, the over-all results do indicate that size of parcel does affect the assessment ratio, with the larger tracts frequently being assessed at a lower percentage of the market value than were the smaller tracts. Many of the properties transferred were lots where acreage was not indicated. Many of the acreages were rural properties and farms and these appeared to have been assessed at lower rates than other types of properties. Of the 2,246 transfers with acreages reported, the average assessment to sales value ratio was only 0.2143 compared with 0.3357 for all properties. Since the larger acreages were assessed lower than smaller parcels the bias seems to have been produced mostly by the treatment of the larger tracts of land.

\section{Assessment Ratios by Improvement}

Properties were grouped by improvements into the following two classes: improved and unimproved. There were 3,977 properties with improvements, 1,144 without, and 2,191 for which improvements were not indicated. 
TABLE 4. Relative Frequency Distribution of Assessment to Sales Values

Ratios in 50 West Virginia Counties, 1971-1972, by Ratio Class

\begin{tabular}{|c|c|c|c|c|c|c|c|c|c|c|c|}
\hline \multirow[b]{2}{*}{ County } & \multicolumn{11}{|c|}{ Ratio Class Limits } \\
\hline & $\begin{array}{l}0.01- \\
0.09 \\
\end{array}$ & $\begin{array}{l}0.1- \\
0.19 \\
\end{array}$ & $\begin{array}{l}0.2- \\
0.29 \\
\end{array}$ & $\begin{array}{l}0.3- \\
0.39 \\
\end{array}$ & $\begin{array}{l}0.4- \\
0.49 \\
\end{array}$ & $\begin{array}{l}0.5- \\
0.59 \\
\end{array}$ & $\begin{array}{l}0.6- \\
0.69 \\
\end{array}$ & $\begin{array}{l}0.7- \\
0.79 \\
\end{array}$ & $\begin{array}{l}0.8- \\
0.89 \\
\end{array}$ & $\begin{array}{l}0.9- \\
0.99 \\
\end{array}$ & $\begin{array}{l}\text { Over } \\
0.99 \\
\end{array}$ \\
\hline \multicolumn{12}{|c|}{ Percent } \\
\hline Barbour & -- & 12.16 & 20.27 & 17.57 & 13.51 & 6.76 & 8.11 & 4.05 & 2.70 & 1.35 & 13.51 \\
\hline Berkeley & 10.38 & 7.55 & 24.53 & 31.13 & 16.04 & 2.83 & 0.94 & 1.89 & -- & 0.94 & 3.77 \\
\hline Boone & 16.16 & 7.07 & 31.31 & 10.10 & 11.11 & 8.08 & 1.01 & 3.03 & -- & 3.03 & 9.09 \\
\hline Braxton & 12.12 & 15.56 & 25.56 & 12.22 & 11.11 & 7.78 & 4.44 & 4.44 & -- & 1.11 & 5.56 \\
\hline Brooke & 3.55 & 4.06 & 13.20 & 32.49 & 26.40 & 11.17 & 2.54 & 2.54 & 1.02 & 1.52 & 1.52 \\
\hline Cabell & 1.68 & 4.13 & 17.96 & 43.15 & 19.51 & 6.33 & 2.84 & 1.42 & 0.78 & 0.52 & 1.68 \\
\hline Calhoun & -- & 15.22 & 28.26 & 19.57 & 17.39 & 6.52 & 2.17 & 2.17 & 4.35 & -- & 4.35 \\
\hline Clay & 8.33 & 2.78 & 16.67 & 12.50 & 20.83 & 11.11 & 8.33 & 1.39 & 1.94 & 4.17 & 6.94 \\
\hline Doddridge & 8.64 & 12.35 & 24.69 & 24.69 & 12.35 & 6.17 & 1.23 & 2.47 & -- & 2.47 & 4.94 \\
\hline Fayette & 6.06 & 18.18 & 29.29 & 22.22 & 17.17 & 3.03 & 2.02 & 1.01 & 1.01 & -- & -- \\
\hline Gilmer & 15.00 & 14.17 & 20.00 & 16.67 & 11.67 & 9.17 & 1.67 & 5.00 & -- & 2.50 & 4.17 \\
\hline Grant & 18.84 & 24.64 & 20.29 & 18.84 & 8.70 & 1.45 & 4.35 & -- & -- & 1.45 & 1.45 \\
\hline Hampshire & 24.00 & 32.00 & 16.00 & 12.00 & 4.00 & 8.00 & -- & -- & -- & -- & 4.00 \\
\hline Hancock & 5.52 & 7.98 & 14.11 & 34.97 & 19.02 & 7.98 & 3.07 & 2.45 & 0.61 & 1.23 & 3.07 \\
\hline Hardy & 25.68 & 12.16 & 20.27 & 24.32 & 5.41 & 1.35 & 2.70 & -- & -- & 1.35 & 6.76 \\
\hline Harrison & -- & -- & -- & -- & -- & 88.89 & -- & -- & 11.11 & -- & -- \\
\hline Jackson & 4.26 & 12.06 & 17.02 & 43.26 & 14.89 & 3.55 & 0.71 & -- & 3.55 & -- & 0.71 \\
\hline Jefferson & 17.65 & 15.69 & 25.49 & 13.73 & 13.73 & 4.90 & 2.94 & 1.96 & 0.98 & -- & 2.94 \\
\hline Logan & 11.90 & 23.81 & 23.81 & 14.29 & 7.14 & 4.76 & 2.38 & 2.38 & 7.14 & -- & 2.38 \\
\hline McDowell & 3.45 & 10.34 & 13.79 & 20.69 & 10.34 & 10.34 & 6.90 & 3.45 & -- & 13.79 & 6.90 \\
\hline Marion & 1.18 & 4.42 & 27.14 & 36.28 & 13.86 & 9.44 & 2.06 & 3.45 & 0.88 & 0.29 & 0.88 \\
\hline
\end{tabular}




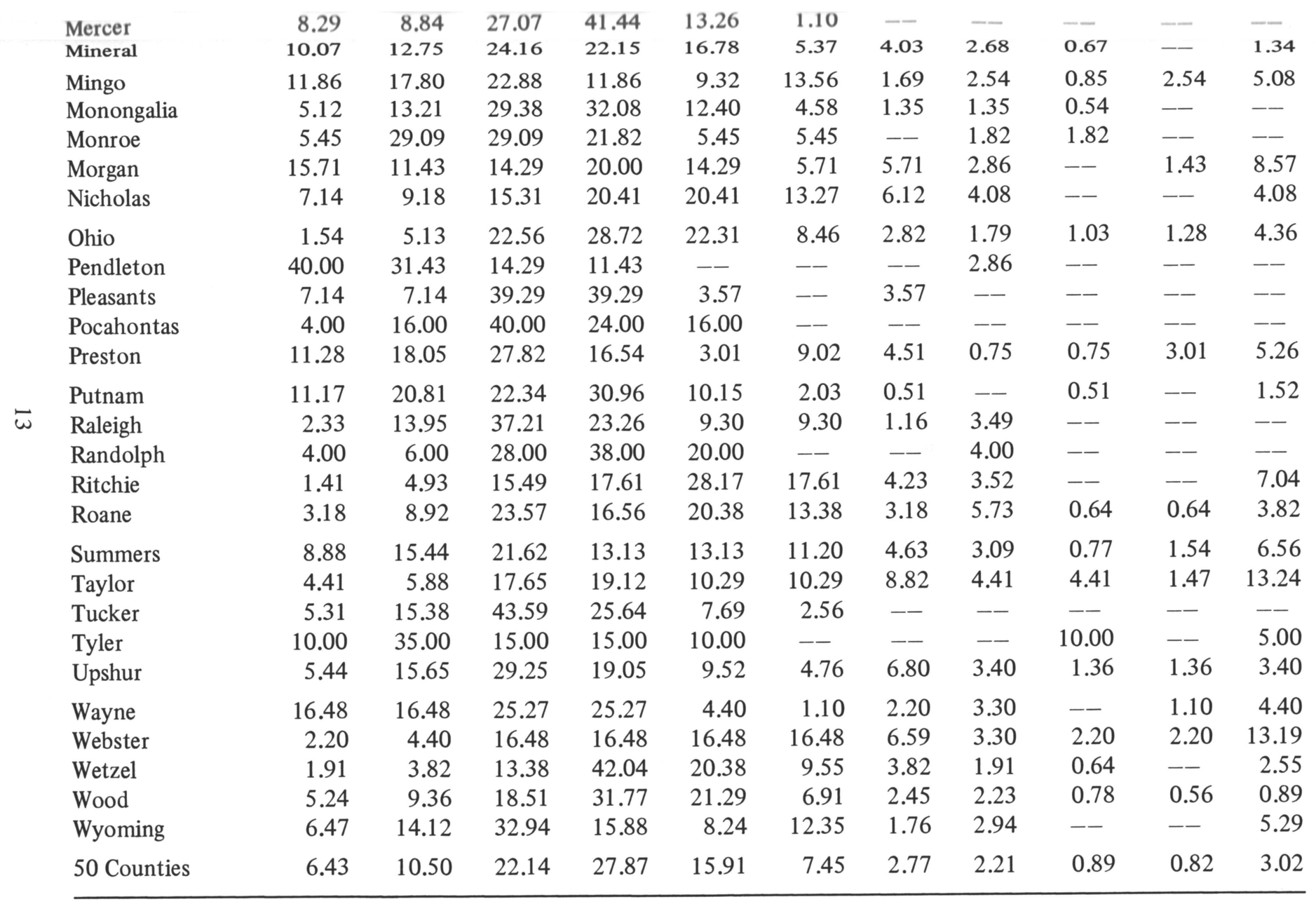


TABLE 5. Numbers and Average Assessment Ratios by Consideration Classes in West Virginia, 1971-1972

\begin{tabular}{|c|c|c|c|c|c|c|c|c|c|c|}
\hline \multirow[b]{2}{*}{ County } & \multicolumn{10}{|c|}{ Consideration Class Limits } \\
\hline & $\$ 1-999$ & $\mathbf{N}$ & $\begin{array}{r}\$ 1,000 \\
9,999 \\
\end{array}$ & $\mathbf{N}$ & $\begin{array}{c}\$ 10,000- \\
24,999\end{array}$ & $\mathbf{N}$ & $\begin{array}{r}\$ 25,000 \\
49,999\end{array}$ & $\mathbf{N}$ & $\begin{array}{c}\$ 50,000 \\
\text { Plus }\end{array}$ & $\mathbf{N}$ \\
\hline Barbour & 0.9049 & 25 & 0.4237 & 38 & 0.2493 & 10 & 0.2389 & 1 & -- & 0 \\
\hline Berkeley & 1.3114 & 7 & 0.3063 & 45 & 0.3035 & 34 & 0.3282 & 19 & 0.5203 & 1 \\
\hline Boone & 0.6920 & 16 & 0.3294 & 69 & 0.2667 & 11 & 0.2508 & 3 & -- & 0 \\
\hline Braxton & 0.5177 & 18 & 0.2922 & 54 & 0.2764 & 15 & 0.2786 & 1 & 0.4848 & 2 \\
\hline Brooke & -- & 0 & 0.4787 & 75 & 0.3766 & 101 & 0.3215 & 20 & 0.3520 & 1 \\
\hline Cabell & 0.8460 & 12 & 0.4414 & 203 & 0.3642 & 349 & 0.3562 & 182 & 0.3232 & 28 \\
\hline Calhoun & 0.7447 & 5 & 0.3856 & 32 & 0.3131 & 10 & 0.1679 & 1 & -- & 0 \\
\hline Clay & 0.7935 & 12 & 0.4417 & 51 & 0.3728 & 8 & 0.3000 & 1 & -- & 0 \\
\hline Doddridge & 0.8070 & 14 & 0.3239 & 56 & 0.2336 & 11 & 0.0144 & 1 & -- & 0 \\
\hline Fayette & 0.2794 & 12 & 0.3248 & 52 & 0.2552 & 28 & 0.3344 & 7 & 0.2587 & 1 \\
\hline Gilmer & 0.5849 & 20 & 0.3115 & 91 & 0.3287 & 26 & 0.0527 & 2 & 0.1060 & 1 \\
\hline Grant & 0.1760 & 4 & 0.2791 & 32 & 0.2365 & 22 & 0.3039 & 7 & 0.1916 & 4 \\
\hline Hampshire & 4.2858 & 1 & 0.2919 & 4 & 0.2086 & 10 & 0.2458 & 6 & 0.0914 & 4 \\
\hline Hancock & 0.5424 & 4 & 0.4144 & 72 & 0.3700 & 83 & 0.3861 & 20 & -- & 0 \\
\hline Hardy & 2.0758 & 5 & 0.2730 & 41 & 0.2329 & 22 & 0.0962 & 5 & 0.0401 & 1 \\
\hline Harrison & 0.5000 & 1 & 0.6000 & 5 & 0.5000 & 3 & -- & 0 & -- & 0 \\
\hline Jackson & 0.5856 & 5 & 0.3033 & 67 & 0.3669 & 60 & 0.4285 & 10 & -- & 0 \\
\hline Jefferson & 0.6259 & 14 & 0.2429 & 63 & 0.2144 & 17 & 0.3767 & 3 & 0.2486 & 5 \\
\hline Logan & 0.3864 & 8 & 0.2886 & 27 & 0.2228 & 9 & -- & 0 & -- & 0 \\
\hline McDowell & 0.6181 & 11 & 0.4023 & 17 & 0.2200 & 1 & -- & 0 & -- & 0 \\
\hline Marion & 0.5232 & 25 & 0.3760 & 171 & 0.3197 & 100 & 0.3234 & 40 & 0.3374 & 3 \\
\hline Marshall & 0.0715 & 1 & 0.3491 & 95 & 0.3224 & 60 & 0.3323 & 20 & -- & 0 \\
\hline Mason & & 0 & 0.3366 & 5 & 0.2866 & 1 & 0.3285 & 2 & 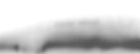 & 0 \\
\hline
\end{tabular}




\begin{tabular}{lrrrrrrrrrr} 
Mineral & $\mathbf{0 . 2 8 0 1}$ & $\mathbf{8}$ & $\mathbf{0 . 3 4 9 0}$ & $\mathbf{7 5}$ & $\mathbf{0 . 3 3 6 3}$ & $\mathbf{5 7}$ & $\mathbf{0 . 3 0 5 5}$ & $\mathbf{9}$ & $\mathbf{0 . 1 9 4 0}$ & $\mathbf{1}$ \\
Mingo & $\mathbf{0 . 7 3 6 9}$ & 20 & 0.2903 & 79 & 0.1930 & 16 & 0.2035 & 3 & - & 0 \\
Monongalia & 0.3732 & 22 & 0.3269 & 95 & 0.2920 & 147 & 0.3050 & 100 & 0.3421 & 7 \\
Monroe & 0.4226 & 6 & 0.2345 & 25 & 0.2230 & 18 & 0.2392 & 5 & 0.3060 & 1 \\
Morgan & 0.2886 & 6 & 0.4933 & 35 & 0.3128 & 15 & 0.2172 & 9 & 0.3293 & 5 \\
Nicholas & 0.4883 & 16 & 0.3840 & 67 & 0.3050 & 15 & -- & 0 & -- & 0 \\
Ohio & 0.2916 & 8 & 0.4876 & 145 & 0.3514 & 162 & 0.3551 & 67 & 0.5164 & 12 \\
Pendleton & 0.3334 & 1 & 0.1674 & 12 & 0.1501 & 9 & 0.1226 & 10 & 0.0586 & 3 \\
Pleasants & 0.4713 & 3 & 0.2348 & 11 & 0.3372 & 13 & 0.3856 & 1 & -- & 0 \\
Pocahontas & -- & 1 & 0.2694 & 16 & 0.2734 & 11 & 0.2400 & 1 & -- & 0 \\
Preston & 0.6419 & 17 & 0.3076 & 72 & 0.2671 & 33 & 0.1109 & 10 & 0.3914 & 1 \\
Putnam & 0.6295 & 13 & 0.2280 & 73 & 0.2693 & 68 & 0.3098 & 44 & 0.2987 & 2 \\
Raleigh & 0.2949 & 7 & 0.3598 & 32 & 0.2797 & 35 & 0.2954 & 13 & -- & 0 \\
Randolph & 0.7813 & 1 & 0.3169 & 29 & 0.3010 & 16 & 0.4111 & 2 & 0.4214 & 2 \\
Ritchie & 0.7339 & 12 & 0.4176 & 110 & 0.3298 & 15 & 0.2669 & 7 & -- & 1 \\
Roane & 0.5487 & 17 & 0.3673 & 102 & 0.3916 & 33 & 0.2205 & 5 & -- & 0 \\
Summers & 0.5958 & 49 & 0.3633 & 165 & 0.2738 & 40 & 0.2001 & 5 & 0.0980 & 1 \\
Taylor & 1.3434 & 6 & 0.4531 & 62 & 0.2676 & 4 & 0.3320 & 2 & 0.3702 & 1 \\
Tucker & - & 0 & 0.2877 & 25 & 0.2360 & 13 & 0.2800 & 2 & -- & 0 \\
Tyler & 0.3383 & 4 & 0.3545 & 11 & 0.2645 & 5 & -- & 0 & -- & 0 \\
Upshur & 0.5439 & 13 & 0.3163 & 93 & 0.3156 & 35 & 0.3366 & 6 & -- & 0 \\
Wayne & 0.9236 & 4 & 0.2681 & 45 & 0.2537 & 38 & 0.3032 & 4 & -- & 0 \\
Webster & 0.8701 & 28 & 0.4019 & 58 & 0.4315 & 5 & -- & 0 & -- & 0 \\
Wetzel & 0.5054 & 16 & 0.4032 & 81 & 0.3403 & 35 & 0.3854 & 25 & -- & 0 \\
Wood & 0.4554 & 28 & 0.3618 & 350 & 0.3552 & 384 & 0.3628 & 120 & 0.3470 & 16 \\
Wyoming & 0.5168 & 35 & 0.2884 & 105 & 0.2801 & 28 & 0.2067 & 2 & -- & 0 \\
50 Counties & 0.5908 & 565 & 0.3614 & 3,418 & 0.3275 & 2,327 & 0.3277 & 837 & 0.3476 & 107 \\
& & & & & & & & & & \\
\hline & & & & & & & &
\end{tabular}


TABLE 6. Average Assessment to Sales Value Ratios in 50 West Virginia Counties, 1971-1972, by Acreage Classes

\begin{tabular}{|c|c|c|c|c|c|c|c|c|c|c|}
\hline \multirow[b]{2}{*}{ County } & \multicolumn{10}{|c|}{ Acreage Ranges } \\
\hline & $0.1-.9$ & $\mathbf{N}$ & $1-4.9$ & $\mathbf{N}$ & $5-24.9$ & $\mathbf{N}$ & $25-99.9$ & $\mathbf{N}$ & 100 Plus & $\mathbf{N}$ \\
\hline Barbour & 0.4887 & 5 & 0.2415 & 6 & 0.4170 & 7 & 0.2816 & 8 & 0.3343 & 5 \\
\hline Berkeley & 0.3250 & 82 & 0.4043 & 17 & 0.1553 & 5 & 0.0918 & 2 & -- & 0 \\
\hline Boone & 0.3334 & 12 & 0.1725 & 8 & 0.1674 & 12 & 0.3207 & 6 & -- & 0 \\
\hline Braxton & 0.2095 & 13 & 0.2401 & 16 & 0.7724 & 9 & 0.2473 & 23 & 0.0833 & 2 \\
\hline Brooke & 0.4051 & 6 & 0.3891 & 16 & 0.3674 & 4 & 0.2980 & 3 & 0.0893 & 2 \\
\hline Cabell & 0.3560 & 20 & 0.2940 & 24 & 0.2003 & 12 & 0.3106 & 7 & 0.4258 & 1 \\
\hline Calhoun & 0.3938 & 5 & 0.3800 & 10 & 0.3280 & 8 & 0.3352 & 13 & 0.2540 & 2 \\
\hline Clay & 0.3410 & 3 & 0.4193 & 14 & 0.4837 & 10 & 0.3939 & 18 & 0.3671 & 6 \\
\hline Doddridge & 0.3399 & 3 & 0.1279 & 7 & 0.2724 & 11 & 0.1690 & 21 & 0.3186 & 9 \\
\hline Fayette & 0.2819 & 2 & 0.2657 & 15 & 0.2973 & 8 & 0.2398 & 8 & 0.2121 & 3 \\
\hline Gilmer & 0.3417 & 11 & 0.3000 & 16 & 0.1791 & 10 & 0.2707 & 52 & 0.2219 & 19 \\
\hline Grant & 0.2150 & 1 & 0.3672 & 10 & 0.1966 & 4 & 0.2475 & 6 & 0.1287 & 7 \\
\hline Hampshire & -- & 0 & 0.2955 & 4 & 0.0640 & 3 & 0.2421 & 6 & 0.1346 & 11 \\
\hline Hancock & 0.4095 & 21 & 0.3946 & 12 & 0.4348 & 1 & -- & 0 & 0.1862 & 1 \\
\hline Hardy & 0.3598 & 11 & 0.2435 & 12 & 0.2528 & 8 & 0.1267 & 9 & 0.1054 & 13 \\
\hline Harrison & -- & 0 & 0.5000 & 1 & -- & 0 & 0.5000 & 1 & 0.5000 & 1 \\
\hline Jackson & 0.2935 & 6 & 0.2535 & 13 & 0.4103 & 8 & 0.2158 & 24 & 0.3310 & 5 \\
\hline Jefferson & -- & 0 & -- & 0 & -- & 0 & -- & 0 & 0.2181 & 1 \\
\hline Logan & -- & 0 & 0.1423 & 4 & 0.0847 & 3 & -- & 0 & -- & 0 \\
\hline McDowell & -- & 0 & 0.0600 & 1 & 0.3858 & 1 & 0.3445 & 1 & -- & 0 \\
\hline Marion & 0.2524 & 5 & 0.3049 & 12 & 0.1835 & 6 & & 11 & 0.2273 & 2 \\
\hline Marshall & 0.3356 & 10 & 0.3301 & 15 & 0.1318 & 6 & 0.3008 & 13 & 0.3095 & 5 \\
\hline Mason & & 0 & & 0 & & 0 & 0.2414 & 3 & - & \\
\hline
\end{tabular}




\begin{tabular}{lrrrrrrrrrr} 
Mercer & 0.2394 & 3 & 0.2668 & 11 & 0.3210 & 10 & 0.2165 & 10 & - & 0 \\
Mineral & $\mathbf{0 . 3 0 2 1}$ & 21 & 0.3204 & 13 & 0.5975 & 3 & 0.1890 & 6 & 0.2313 & 5 \\
Mingo & 0.2598 & 25 & 0.2170 & 15 & 0.1837 & 5 & 0.1334 & 2 & 0.0845 & 2 \\
Monongalia & 0.2991 & 26 & 0.2190 & 22 & 0.1349 & 17 & 0.1978 & 16 & -- & 0 \\
Monroe & 0.2946 & 1 & 0.3761 & 3 & 0.3062 & 3 & 0.1789 & 17 & 0.2300 & 16 \\
Morgan & 0.2885 & 7 & 0.0269 & 17 & 0.4078 & 16 & 0.1416 & 6 & 0.1826 & 3 \\
Nicholas & 0.4584 & 3 & 0.3822 & 15 & 0.3117 & 15 & 0.2546 & 8 & 0.3660 & 3 \\
Ohio & 0.3431 & 6 & 0.3305 & 13 & 0.4030 & 6 & 0.1756 & 2 & 0.1813 & 1 \\
Pendleton & 0.3036 & 5 & 0.2109 & 4 & 0.1402 & 5 & 0.1210 & 5 & 0.0706 & 14 \\
Pleasants & 0.3235 & 2 & 0.2928 & 1 & 0.2755 & 5 & 0.2732 & 4 & -- & 0 \\
Pocahontas & 0.1940 & 2 & 0.1563 & 2 & 0.3986 & 3 & -- & 0 & 0.2639 & 3 \\
Preston & 0.2591 & 14 & 0.2938 & 15 & 0.1492 & 17 & 0.1361 & 26 & 0.1516 & 9 \\
Putnam & 0.2575 & 15 & 0.2412 & 16 & 0.1705 & 9 & 0.1355 & 18 & 0.1545 & 7 \\
Raleigh & -- & 0 & 0.5100 & 1 & 0.1680 & 1 & 0.1080 & 1 & -- & 0 \\
Randolph & 0.2829 & 1 & 0.2740 & 6 & 0.1721 & 2 & 0.2119 & 4 & 0.3077 & 1 \\
Ritchie & 0.4337 & 6 & 0.4000 & 15 & 0.3878 & 15 & 0.2729 & 29 & 0.2534 & 15 \\
Roane & 0.4569 & 8 & 0.3091 & 13 & 0.3641 & 18 & 0.2767 & 43 & 0.3660 & 28 \\
Summers & 0.2081 & 7 & 0.2739 & 25 & 0.1916 & 26 & 0.2438 & 43 & 0.3071 & 16 \\
Taylor & 0.3272 & 3 & 0.3097 & 6 & 0.3697 & 3 & 0.2157 & 1 & -- & 0 \\
Tucker & 0.1263 & 1 & 0.0129 & 3 & -- & 0 & 0.1622 & 3 & 0.1772 & 2 \\
Tyler & -- & 0 & -- & 0 & -- & 0 & 0.1956 & 8 & 0.4000 & 1 \\
Upshur & 0.2568 & 23 & 0.3511 & 19 & 0.1887 & 11 & 0.3405 & 23 & 0.3057 & 5 \\
Wayne & 0.2591 & 11 & 0.2812 & 10 & 0.1846 & 15 & 0.1479 & 14 & 0.1745 & 1 \\
Webster & 0.4743 & 4 & 0.4134 & 14 & 0.3421 & 20 & 0.3233 & 12 & 0.7693 & 1 \\
Wetzel & 0.5850 & 5 & 0.2439 & 6 & 0.3305 & 9 & 0.3824 & 20 & 0.3259 & 10 \\
Wood & 0.3485 & 29 & 0.2949 & 36 & 0.2732 & 16 & 0.2081 & 24 & 0.2223 & 9 \\
Wyoming & 0.3146 & 20 & 0.2113 & 13 & 0.1667 & 4 & 0.2054 & 6 & -- & 0 \\
50 Counties & 0.3235 & 468 & 0.2994 & 559 & 0.2947 & 407 & 0.2249 & 615 & 0.1852 & 250 \\
\hline & & & & & & & & &
\end{tabular}


Thirty-five of the 44 counties with usable data had higher ratios for improved property than for unimproved.

For the state, the average assessment to consideration ratio for improved properties was 0.3533 compared with 0.2120 for unimproved properties (Table 7). The largest average assessment for unimproved property was 0.5360 in Harrison County, but there were only five observations in that sub-group. The smallest assessment ratio was 0.0760 for unimproved properties in Hardy County and occurred with 16 observations. The presence of improvements seemingly did affect the assessment ratio, and if this is true, it means that buildings are assuming a relatively larger portion of the tax burden than is land.

\section{Assessment Ratios by Location}

Location of properties were grouped in the following three classes: urban, suburban, and rural. Location was not indicated for 1,539 sales. The highest average assessment ratio for all counties was for the urban properties, 0.3811, and the second highest for the suburban, 0.3427 , while the rural properties had the lowest average assessment ratio, 0.2755 (Table 8). Five of the 50 counties did not report location for any of their sales while two of the 50 counties had no data for two of the classes. The assessment ratio was larger for urban than suburban properties in 24 out of 34 counties and than for rural properties in 38 out of 42 counties (not all counties had properties in all three groups).

The assessment to consideration ratio by location indicates that properties closer to the cities within a county are likely to have relatively higher assessments. The more urban classes appear to be assessed at a higher percentage of market value than the less urban classes. This can be seen where there is an assessment ratio of 0.35 or higher which occurred in 25 counties for the urban class, in 13 counties in the suburban class, and in only five counties in the rural class. An assessment ratio of 0.25 or less occurred in one county for the urban class, eight counties for the suburban class, and 17 counties for the rural class. These results are consistent with those for acreages which are mainly rural and had average assessment ratios lower than for other properties.

\section{TABLE 7. Average Assessment to Sales Value Ratios in 44 West Virginia Counties, 1971-1972, for Improved and Unimproved Properties}

\begin{tabular}{lcrcr}
\hline \hline County & Improved & N & Unimproved & N \\
\hline Barbour & 0.2396 & 8 & 0.2652 & 11 \\
Berkeley & 0.3447 & 73 & 0.1530 & 31 \\
Boone & -- & 0 & 0.4167 & 8 \\
Braxton & 0.3844 & 47 & 0.1771 & 36 \\
Brooke & 0.3875 & 66 & 0.4307 & 24
\end{tabular}




\begin{tabular}{|c|c|c|c|c|}
\hline County & Improved & $\mathbf{N}$ & Unimproved & $\mathbf{N}$ \\
\hline Cabell & 0.3640 & 503 & 0.2681 & 52 \\
\hline Calhoun & 0.3181 & 30 & 0.3488 & 8 \\
\hline Doddridge & 0.3117 & 3 & 0.4746 & 3 \\
\hline Fayette & 0.2649 & 60 & 0.2846 & 23 \\
\hline Gilmer & 0.3567 & 28 & 0.2633 & 23 \\
\hline Grant & 0.2540 & 35 & 0.1259 & 15 \\
\hline Hancock & 0.4026 & 36 & 0.3841 & 28 \\
\hline Hardy & 0.2788 & 28 & 0.0760 & 16 \\
\hline Harrison & 0.5360 & 5 & 0.5000 & 4 \\
\hline Jackson & 0.3774 & 103 & 0.2275 & 32 \\
\hline Jefferson & 0.2749 & 34 & 0.1803 & 65 \\
\hline McDowell & 0.4095 & 11 & 0.3734 & 18 \\
\hline Marion & 0.3393 & 303 & 0.2050 & 34 \\
\hline Marshall & 0.3374 & 114 & 0.1368 & 28 \\
\hline Mason & 0.3202 & 7 & 0.4429 & 1 \\
\hline Mercer & 0.3251 & 147 & 0.2086 & 33 \\
\hline Mineral & 0.3528 & 100 & 0.1547 & 34 \\
\hline Mingo & 0.2707 & 86 & 0.1868 & 27 \\
\hline Monongalia & 0.3150 & 294 & 0.2080 & 56 \\
\hline Monroe & 0.2500 & 28 & 0.1717 & 11 \\
\hline Nicholas & 0.3604 & 68 & 0.3010 & 30 \\
\hline Ohio & 0.4221 & 273 & 0.2029 & 27 \\
\hline Pendleton & 0.2267 & 4 & 0.0891 & 12 \\
\hline Pleasants & 0.3466 & 14 & 0.2194 & 10 \\
\hline Pocahontas & 0.2380 & 4 & 0.1844 & 2 \\
\hline Preston & 0.2536 & 51 & 0.0876 & 17 \\
\hline Putnam & 0.2913 & 41 & 0.0880 & 3 \\
\hline Raleigh & 0.2967 & 71 & 0.4706 & 13 \\
\hline Randolph & 0.3510 & 34 & 0.2929 & 9 \\
\hline Ritchie & 0.1977 & 13 & 0.2385 & 25 \\
\hline Roane & 0.3608 & 117 & 0.3404 & 15 \\
\hline Summers & 0.2938 & 78 & 0.2574 & 39 \\
\hline Taylor & 0.4455 & 41 & 0.1424 & 7 \\
\hline Tucker & 0.3157 & 16 & 0.0862 & 2 \\
\hline Upshur & 0.2137 & 4 & 0.1871 & 3 \\
\hline Wayne & 0.2825 & 31 & 0.1269 & 14 \\
\hline Wetzel & 0.3789 & 120 & 0.2350 & 31 \\
\hline Wood & 0.3709 & 705 & 0.1778 & 186 \\
\hline Wyoming & 0.2953 & 116 & 0.2121 & 44 \\
\hline 44 Counties & 0.3533 & 3,977 & 0.2120 & 1,144 \\
\hline
\end{tabular}


TABLE 8. Average Assessment to Sales Value

Ratios in 45 West Virginia Counties

for 1971-1972 by Location Class

\begin{tabular}{|c|c|c|c|c|c|c|}
\hline \multirow[b]{2}{*}{ County } & \multicolumn{6}{|c|}{ Location Class Limits } \\
\hline & Urban & $\mathbf{N}$ & Suburban & $\mathbf{N}$ & Rural & $\mathbf{N}$ \\
\hline Barbour & 0.3249 & 7 & 0.2714 & 5 & 0.3411 & 20 \\
\hline Berkeley & 0.3743 & 37 & 0.3388 & 17 & 0.2370 & 51 \\
\hline Braxton & 0.3125 & 18 & 0.2918 & 4 & 0.3623 & 70 \\
\hline Brooke & 0.3870 & 75 & 0.3705 & 33 & 0.3808 & 40 \\
\hline Cabell & 0.3830 & 346 & 0.3301 & 153 & 0.3023 & 63 \\
\hline Calhoun & 0.4369 & 4 & -- & 0 & 0.3160 & 31 \\
\hline Doddridge & 0.3244 & 5 & -- & 0 & 0.3208 & 29 \\
\hline Fayette & 0.3646 & 25 & 0.2276 & 5 & 0.2583 & 54 \\
\hline Gilmer & 0.3736 & 16 & 0.2898 & 16 & 0.2224 & 103 \\
\hline Grant & 0.3130 & 13 & 0.3820 & 8 & 0.1662 & 30 \\
\hline Hancock & 0.3986 & 64 & 0.4916 & 9 & 0.3321 & 13 \\
\hline Hardy & 0.3639 & 25 & -- & 0 & 0.0974 & 19 \\
\hline Harrison & 0.5478 & 6 & 0.5000 & 1 & 0.5000 & 2 \\
\hline Jackson & 0.4095 & 63 & 0.4161 & 1 & 0.2996 & 75 \\
\hline Jefferson & 0.3395 & 19 & 0.1186 & 5 & 0.2489 & 75 \\
\hline Logan & 0.2060 & 6 & -- & 0 & 0.2981 & 27 \\
\hline McDowell & 0.4095 & 11 & -- & 0 & 0.3734 & 18 \\
\hline Marion & 0.3527 & 205 & 0.3057 & 79 & 0.2667 & 55 \\
\hline Marshall & 0.3097 & 67 & 0.4085 & 17 & 0.3113 & 58 \\
\hline Mason & 0.3377 & 5 & -- & 0 & 0.2414 & 3 \\
\hline Mercer & 0.3411 & 76 & 0.3442 & 10 & 0.2929 & 95 \\
\hline Mineral & 0.3728 & 54 & 0.2129 & 4 & 0.3220 & 76 \\
\hline Mingo & 0.3386 & 31 & 0.3123 & 1 & 0.2208 & 82 \\
\hline Monongalia & 0.3369 & 4 & 0.3174 & 258 & 0.2466 & 107 \\
\hline Monroe & 0.3611 & 6 & 0.2605 & 2 & 0.2042 & 34 \\
\hline Nicholas & 0.3800 & 16 & 0.4026 & 8 & 0.3387 & 74 \\
\hline Ohio & 0.4548 & 253 & 0.3479 & 79 & 0.3004 & 53 \\
\hline Pendleton & -- & 0 & -- & 0 & 0.1880 & 1 \\
\hline Pleasants & 0.3500 & 13 & -- & 0 & 0.2788 & 12 \\
\hline Pocahontas & 0.3401 & 6 & 0.1656 & 1 & 0.2665 & 13 \\
\hline Preston & 0.3740 & 23 & -- & 0 & 0.1915 & 56 \\
\hline Putnam & -- & 0 & 0.1502 & 2 & 0.1449 & 10 \\
\hline Raleigh & 0.3279 & 41 & 0.3300 & 12 & 0.2326 & 31 \\
\hline Randolph & 0.3710 & 22 & 0.3558 & 6 & 0.2788 & 15 \\
\hline Ritchie & 0.3323 & 19 & 0.2182 & 6 & 0.2282 & 30 \\
\hline
\end{tabular}


Location Class Limits

\begin{tabular}{lcrcrcr}
\cline { 2 - 7 } County & Urban & N & Suburban & N & Rural & N \\
\hline Roane & 0.4074 & 33 & 0.3523 & 26 & 0.3442 & 83 \\
Summers & 0.3472 & 44 & 0.4451 & 5 & 0.2637 & 152 \\
Taylor & 0.5017 & 29 & 0.3130 & 5 & 0.3689 & 14 \\
Tucker & 0.2878 & 27 & 0.3894 & 3 & 0.1653 & 8 \\
Tyler & 0.4534 & 1 & -- & 0 & -- & 0 \\
Upshur & 0.3533 & 45 & 0.1667 & 1 & 0.2869 & 100 \\
Wayne & 0.3007 & 18 & 0.2456 & 9 & 0.2344 & 39 \\
Wetzel & 0.3747 & 82 & 0.3835 & 10 & 0.3669 & 61 \\
Wood & 0.3636 & 115 & 0.3630 & 645 & 0.2932 & 133 \\
Wyoming & 0.3288 & 38 & 0.2693 & 50 & 0.2485 & 80 \\
45 Counties & 0.3811 & 2,028 & 0.3427 & 1,504 & 0.2755 & 2,241 \\
\hline
\end{tabular}

\section{Assessment Ratios by Tax Class}

For tax purposes, real properties are grouped into three classes: Class II, Class III, and Class IV. Class II property is real property used for residential and farm purposes; Class III property is property exclusive of Class II property located outside of municipalities; and Class IV property is property exclusive of Class II property located within municipalities. Some 195 sales did not have a tax class indicated.

The highest average assessment ratio for the state was in Class IV, 0.4005, the second highest in Class II, 0.3338 , and the lowest ratio of the indicated classes was Class III, 0.2655 (Table 9). Twenty-two of the 50 counties followed the same pattern. The ratios were larger for Class II than Class III properties in 31 out of 48 counties. Class II property ratios were larger than Class IV only in 14 out of 46 counties. The indication of these findings seems to establish class as a factor that affects the assessment ratio.

These findings tie in with the findings for location. Class IV property had the largest ratio and it is located within a municipality; Class II which can be in either location has the next largest ratio, and Class III which is always outside of a municipality, had the smallest ratio.

\section{Assessment Ratios by Land Use}

The assessment ratios were grouped by land use into the following eight classes: (1) residence, owner-occupied and rental, (2) farm, meadow or grazing, (3) commercial, including parking or campsite, (4) woodland or timberland, (5) commercial and residential, (6) homesite or building site, (7) recreation, and (8) vacant or idle. Present use was not indicated for 1,543 of the properties. There was only one observation for recreation and it is omitted from the analysis. 
TABLE 9. Average Assessment to Sales Value

Ratios in 50 West Virginia Counties,

for 1971-1972 by Property Tax Class

\begin{tabular}{lrrrrrr}
\hline \multicolumn{7}{c}{ Property Tax Class Limits } \\
County & Class II & \multicolumn{1}{c}{ N } & Class III & N & Class IV & N \\
\hline Barbour & 0.4076 & 25 & 0.3019 & 7 & 0.3142 & 5 \\
Berkeley & 0.3201 & 57 & 0.2443 & 29 & 0.4255 & 18 \\
Boone & 0.3159 & 48 & 0.3369 & 47 & 0.3095 & 2 \\
Braxton & 0.2527 & 68 & 0.4746 & 12 & 0.3937 & 6 \\
Brooke & 0.3878 & 168 & 0.2886 & 10 & 0.3536 & 14 \\
Cabell & 0.3600 & 564 & 0.2490 & 64 & 0.3703 & 146 \\
Calhoun & 0.3408 & 39 & 0.3343 & 7 & 0.5600 & 1 \\
Clay & 0.4184 & 37 & 0.4441 & 12 & 0.3000 & 1 \\
Doddridge & 0.3028 & 25 & 0.1244 & 10 & 0.3053 & 2 \\
Fayette & 0.2982 & 83 & 0.2014 & 13 & 0.1685 & 2 \\
Gilmer & 0.2353 & 105 & 0.3206 & 26 & 0.3871 & 9 \\
Grant & 0.1990 & 30 & 0.2468 & 24 & 0.3449 & 14 \\
Hampshire & 0.1686 & 23 & 0.1241 & 2 & -- & 0 \\
Hancock & 0.3758 & 124 & 0.2976 & 13 & 0.4447 & 41 \\
Hardy & 0.2196 & 42 & 0.0749 & 24 & 0.3955 & 8 \\
Harrison & 0.5321 & 7 & -- & 0 & 0.5000 & 2 \\
Jackson & 0.3679 & 98 & 0.2852 & 20 & 0.3775 & 21 \\
Jefferson & 0.2614 & 28 & 0.2058 & 61 & 0.3677 & 7 \\
Logan & 0.2691 & 16 & 0.3535 & 12 & 0.1683 & 3 \\
McDowell & 0.3998 & 17 & 0.4872 & 4 & 0.3813 & 8 \\
Marion & 0.3399 & 230 & 0.2400 & 41 & 0.3489 & 66 \\
Marshall & 0.3392 & 112 & 0.2992 & 37 & 0.3121 & 26 \\
Mason & 0.3202 & 7 & 0.4429 & 1 & -- & 0 \\
Mercer & 0.3274 & 130 & 0.2389 & 40 & 0.3324 & 11 \\
Mineral & 0.3267 & 104 & 0.3579 & 31 & 0.3952 & 14 \\
Mingo & 0.2675 & 62 & 0.1844 & 37 & 0.3205 & 17 \\
Monongalia & 0.2996 & 259 & 0.3098 & 85 & 0.3866 & 18 \\
Monroe & 0.2379 & 37 & 0.2320 & 18 & -- & 0 \\
Morgan & 0.2628 & 32 & 0.2774 & 27 & 0.5105 & 9 \\
Nicholas & 0.3520 & 62 & 0.3539 & 28 & 0.3478 & 8 \\
Ohio & 0.3412 & 262 & 0.2474 & 16 & 0.5177 & 115 \\
Pendleton & 0.1328 & 10 & 0.0699 & 9 & 0.3042 & 3 \\
Pleasants & 0.3349 & 19 & 0.3394 & 5 & 0.2573 & 4 \\
Pocahontas & 0.2884 & 24 & 0.3213 & 5 & -- & 0 \\
Preston & 0.2671 & 75 & 0.1301 & 42 & 0.3948 & 16 \\
& & & 22 & & & \\
& & & & & &
\end{tabular}


Property Tax Class Limits

\begin{tabular}{lrrrrrr}
\cline { 2 - 6 } County & Class II & N & Class III & N & Class IV & N \\
\hline Putnam & 0.2913 & 130 & 0.2496 & 62 & 0.0827 & 7 \\
Raleigh & 0.2933 & 54 & 0.2655 & 17 & 0.3472 & 16 \\
Randolph & 0.3198 & 31 & 0.2063 & 12 & 0.4587 & 7 \\
Ritchie & 0.3684 & 101 & 0.2340 & 25 & 0.2130 & 19 \\
Roane & 0.3809 & 118 & 0.2071 & 30 & 0.4150 & 8 \\
Summers & 0.2992 & 190 & 0.2329 & 44 & 0.3897 & 24 \\
Taylor & 0.3777 & 38 & 0.3596 & 16 & 0.5257 & 21 \\
Tucker & 0.2556 & 26 & -- & 0 & 0.2838 & 14 \\
Tyler & 0.3009 & 15 & -- & 0 & 0.3215 & 5 \\
Upshur & 0.3150 & 93 & 0.3236 & 33 & 0.3392 & 20 \\
Wayne & 0.2699 & 83 & 0.1161 & 7 & 0.4303 & 1 \\
Webster & 0.4155 & 66 & 0.3721 & 19 & 0.5234 & 6 \\
Wetzel & 0.3726 & 120 & 0.1671 & 5 & 0.3992 & 28 \\
Wood & 0.3665 & 532 & 0.2897 & 149 & 0.3589 & 217 \\
Wyoming & 0.2543 & 77 & 0.2767 & 64 & 0.3545 & 29 \\
50 Counties & 0.3338 & 4,758 & 0.2655 & 1,319 & 0.4005 & 1,040 \\
\hline
\end{tabular}

The state average ratios for those classes that were represented went from high to low as follows: commercial, residence, commercial and residential, homesite or building site, farm, meadow or grazing, vacant, and woodland or timberland (Table 10). The ratios ranged from 0.4776 to 0.1709 . In 16 of the 50 counties the farm, meadow or grazing class there had at most one observation while the homesite or building site group was concentrated in three counties.

The following counties were not included in Table 10 because of the low number of observations: Boone, Clay, Gilmer, Hancock, Harrison, Logan, Mason, Mercer, Pocahontas, and Upshur.

The residence class is more likely to be in an urban or suburban location and should on the basis of known findings be expected to have a relatively large assessment ratio figure. Also, the commercial class probably is a more urban class. The assessment ratio was 0.4776 for this category, which was the highest ratio of all the categories.

The farm, meadow, and grazing class is more rural and the assessment ratio reflects this with a ratio of 0.2621 . Woodland and timberland is a rural class and has the lowest ratio of all the categories with 0.1709 . This, however, was associated with only 22 observations.

The last category, which is vacant or idle, had an assessment ratio of 0.1896 . This is consistent with the previous findings that the presence of improvements tends to be associated with an increase in the size of the assessment ratio. 
TABLE 10. Average Assessment to Sales Value Ratio

for 40 West Virginia Counties, 1971-1972 by Present Land Use Classes

Land Use Class

\begin{tabular}{lrrrrrrrrrrrrrrr}
\hline County & Resowr $^{\mathbf{a}}$ & $\mathbf{N}$ & Fgh $^{\mathbf{b}}$ & $\mathbf{N}$ & Comm $^{\mathbf{c}}$ & $\mathbf{N}$ & Woodld $^{\mathbf{d}}$ & $\mathbf{N}$ & Commres $^{\mathbf{e}}$ & $\mathbf{N}$ & Homebl $^{\mathbf{f}}$ & $\mathbf{N}$ & Vacant $^{\mathbf{g}}$ & $\mathbf{N}$ \\
\hline Barbour & 0.4099 & 10 & 0.3605 & 5 & -- & 0 & -- & 0 & 0.4167 & 1 & -- & 0 & 0.2686 & 5 \\
Berkeley & 0.3413 & 72 & 0.0625 & 1 & -- & 0 & -- & 0 & 0.4264 & 4 & -- & 0 & 0.2538 & 15 \\
Braxton & 0.2723 & 24 & 0.4230 & 5 & 0.7236 & 4 & 0.1362 & 6 & 0.0934 & 3 & 0.2954 & 18 & 0.1528 & 30 \\
Brooke & 0.3881 & 182 & 0.3530 & 5 & 0.0720 & 1 & -- & 0 & 0.3381 & 7 & -- & 0 & -- & 0 \\
Cabell & 0.3680 & 640 & 0.2577 & 8 & 0.3060 & 4 & -- & 0 & 0.3544 & 36 & -- & 0 & 0.2133 & 79 \\
Calhoun & 0.3326 & 16 & 0.3104 & 21 & 0.5143 & 2 & -- & 0 & 0.3108 & 2 & -- & 0 & -- & 0 \\
Doddridge & 0.3306 & 9 & 0.2527 & 18 & -- & 0 & -- & 0 & 0.2467 & 1 & -- & 0 & 0.4017 & 4 \\
Fayette & 0.3014 & 84 & 0.2553 & 2 & -- & 0 & -- & 0 & -- & 0 & -- & 0 & 0.0820 & 13 \\
Grant & 0.2303 & 43 & 0.1339 & 6 & -- & 0 & -- & 0 & 0.3748 & 7 & -- & 0 & 0.3422 & 9 \\
Hampshire & 0.2152 & 7 & 0.2683 & 7 & -- & 0 & -- & 0 & -- & 0 & -- & 0 & 0.0971 & 10 \\
Hardy & 0.2715 & 41 & 0.1780 & 3 & -- & 0 & -- & 0 & 0.1923 & 2 & 0.3250 & 1 & 0.0934 & 23 \\
Jackson & 0.3866 & 67 & 0.2988 & 23 & 0.4260 & 1 & 0.1740 & 2 & 0.2902 & 4 & 0.3876 & 16 & 0.1884 & 18 \\
Jefferson & 0.2704 & 39 & -- & 6 & -- & 0 & -- & 0 & -- & 0 & -- & 0 & 0.2215 & 55 \\
McDowell & 0.4212 & 28 & -- & 0 & -- & 0 & -- & 0 & 0.2200 & 1 & -- & 0 & -- & 0 \\
Marion & 0.3405 & 298 & 0.3000 & 1 & -- & 0 & -- & 0 & 0.3262 & 8 & -- & 0 & 0.2012 & 32 \\
Marshall & 0.3500 & 120 & 0.3112 & 16 & 0.2561 & 3 & -- & 0 & 0.7848 & 1 & -- & 0 & 0.1446 & 35 \\
Mineral & 0.3402 & 112 & 0.2485 & 8 & 0.2955 & 6 & 0.0643 & 1 & 0.4693 & 1 & 0.4400 & 1 & 0.3266 & 28 \\
Mingo & 0.2570 & 108 & 0.0286 & 1 & -- & 0 & -- & 0 & 0.1653 & 4 & -- & 0 & -- \\
Monongalia & 0.3565 & 17 & 0.4252 & 6 & 0.3079 & 5 & -- & 0 & -- & 0 & 0.3129 & 274 & 0.2893 & 37 \\
Monroe & 0.1953 & 3 & 0.1988 & 16 & -- & 0 & 0.1541 & 2 & -- & 0 & 0.1667 & 1 & -- & 0
\end{tabular}




$\begin{array}{lrrrrrrrrrrrrrr}\text { Morgan } & 0.2932 & 40 & 0.2331 & 6 & 0.4446 & 3 & -- & 0 & 0.5629 & 5 & -- & 0 & 0.2901 & 12 \\ \text { Nicholas } & 0.3874 & 53 & 0.2596 & 11 & 0.3423 & 5 & -- & 0 & -- & 0 & -- & 0 & 0.2967 & 26 \\ \text { Ohio } & 0.3669 & 311 & 0.1882 & 6 & 0.5808 & 21 & -- & 0 & 0.4399 & 19 & -- & 0 & 0.1056 & 26 \\ \text { Pendleton } & 0.1815 & 6 & 0.0946 & 5 & -- & 0 & -- & 0 & 0.2658 & 2 & 0.2412 & 2 & 0.0737 & 9 \\ \text { Pleasants } & 0.3170 & 15 & -- & 0 & -- & 0 & -- & 0 & -- & 0 & 0.3703 & 7 & 0.1243 & 5 \\ \text { Preston } & 0.2612 & 49 & 0.3754 & 2 & -- & 0 & -- & 0 & -- & 0 & -- & 0 & 0.0626 & 5 \\ \text { Putnam } & 0.3099 & 102 & 0.1601 & 29 & -- & 4 & -- & 0 & 0.1833 & 1 & -- & 0 & 0.1862 & 59 \\ \text { Raleigh } & 0.3028 & 70 & -- & 0 & -- & 0 & -- & 0 & 0.2280 & 3 & -- & 0 & 0.3036 & 11 \\ \text { Randolph } & 0.3318 & 38 & 0.4940 & 1 & 0.2276 & 0 & 0.2276 & 2 & -- & 0 & 0.4167 & 1 & 0.1355 & 6 \\ \text { Ritchie } & 0.3484 & 58 & 0.3977 & 15 & -- & 1 & -- & 0 & -- & 0 & -- & 0 & 0.1214 & 12 \\ \text { Roane } & 0.4234 & 55 & 0.3447 & 74 & 0.0925 & 1 & 0.3455 & 3 & 0.3776 & 2 & 0.2786 & 1 & 0.3822 & 16 \\ \text { Summers } & 0.3182 & 172 & -- & 0 & 0.0844 & 1 & 0.2667 & 1 & 0.2884 & 2 & -- & 0 & 0.2201 & 53 \\ \text { Taylor } & 0.4379 & 53 & 0.2328 & 8 & 0.3038 & 1 & -- & 0 & -- & 0 & 0.5188 & 1 & 0.2000 & 4 \\ \text { Tucker } & 0.2969 & 30 & 0.1457 & 4 & 0.2070 & 1 & -- & 0 & -- & 0 & -- & 0 & 0.0862 & 2 \\ \text { Tyler } & 0.3013 & 13 & 0.2750 & 3 & 0.1894 & 1 & -- & 0 & -- & 0 & -- & 0 & -- & 0 \\ \text { Wayne } & 0.2734 & 21 & 0.3000 & 1 & -- & 0 & -- & 0 & -- & 0 & 0.1426 & 2 & 0.1975 & 12 \\ \text { Webster } & 0.4124 & 70 & 0.1858 & 2 & -- & 0 & -- & 0 & 0.5836 & 3 & -- & 0 & 0.3537 & 16 \\ \text { Wetzel } & 0.3819 & 101 & 0.3376 & 28 & 1.1434 & 1 & -- & 0 & 0.2928 & 2 & -- & 0 & 0.2535 & 22 \\ \text { Wood } & 0.3747 & 680 & -- & 0 & 0.2986 & 9 & 0.1740 & 2 & 0.3207 & 20 & -- & 0 & 0.1748 & 36 \\ \text { Wyoming } & 0.2797 & 111 & -- & 0 & 0.3390 & 5 & -- & 0 & 0.3307 & 5 & 0.5000 & 2 & 0.2291 & 46 \\ \text { 40 Counties } & 0.3543 & 4,014 & 0.2621 & 366 & 0.4776 & 81 & 0.1709 & 22 & 0.3450 & 146 & 0.3163 & 328 & 0.1896 & 811 \\ & & & & & & & & & & & & & \end{array}$

$a_{\text {residence, owner-occupied }}$

$\mathrm{b}_{\text {farm, meadow or grazing }}$

commercial

d woodland $\mathrm{e}_{\text {commercial and residential }}$

$\mathrm{f}_{\text {homesite or building site }}$

$\mathrm{g}_{\text {vacant or idle }}$ 


\section{Assessment Ratios by Zoning}

The properties were grouped by zoning into the following three zone classes: residential, commercial, and farm. However, only 771 had a zone indicated and 729 of these were zoned residential. Nearly all were within seven counties. The appropriate comparison, due to the low numbers for most zoned classes, is between the zoned and not zoned, both within counties, and for the state. Since most properties where zoning was not indicated probably were not zoned, the not indicated category will be used as a proxy for not zoned. Because there were 6,299 properties where zoning was not indicated, the not zoned category was 6,541 properties compared to the 771 zoned properties. Zoning more usually is associated with urbanization.

There were seven counties that had some form of zoning indicated: Brooke, Cabell, Harrison, Marion, Monongalia, Morgan, and Taylor (Table 11). Brooke County, however, had only one sale reported with zoning indicated. Cabell County had assessment ratios of 0.3629 for residential, 0.3492 for commercial, and 0.2237 for farm compared to 0.3585 for not indicated. The assessment ratios for the county were comparable to those for the state, with residential ratios the highest, followed by commercial and farm. Harrison County had an assessment ratio of 0.5481 for residential and 0.5000 for not indicated. Marion County had an assessment ratio of 0.3492 for residential and 0.2163 for farm compared to 0.3306 for not indicated. Monongalia County had an assessment ratio of 0.3117 for residential compared to 0.3050 for zoning not indicated. Taylor County had an assessment ratio of 0.4814 for residential and 0.0494 for farm, compared to 0.3637 with no zoning or not indicated.

For the counties with zoning those properties with zoning appeared to be assessed slightly higher than those not zoned or with zoning not indicated. Since zoned properties are usually within incorporated areas the locational factor may have been more important than zoning.

\section{COMPARISONS WITH PREVIOUS STUDIES}

In West Virginia, there have been two previous studies dealing with real estate and comparing the assessed value of the property with the actual market value received through sales. The first study was by Armentrout and Haygood for 1950 and the other was by Colyer and Templeton for 1968-69. Each study will be compared with the other as well as with the results reported in this study. The average ratios by counties for all three studies are given in Table 12 .

\section{Armentrout-Haygood Study}

The Armentrout-Haygood study (1950) compared the price of real estate sold in 1950 with its assessed value. For each of the 48 counties that were included in the study, the real estate sold was divided into seven different classes: (1) unimproved lots outside corporate limits; (2) improved lots outside of corporate limits; (3) those properties of 20 acres or more outside corporate 
TABLE 11. Average Assessment to Sales Value Ratios, 1971-72, by Zoning Class

\begin{tabular}{|c|c|c|c|c|c|c|c|c|c|c|c|c|}
\hline \multirow[b]{2}{*}{ County } & \multicolumn{12}{|c|}{ Zone Class } \\
\hline & $\begin{array}{l}\text { Resi } \\
\text { dential }\end{array}$ & $\mathbf{N}$ & $\begin{array}{c}\text { Commer- } \\
\text { cial }\end{array}$ & $\mathbf{N}$ & Farm & $\mathbf{N}$ & $\begin{array}{c}\text { Zoning- } \\
\text { Yes }\end{array}$ & $\mathbf{N}$ & $\begin{array}{l}\text { Zoning- } \\
\text { No }\end{array}$ & $\mathbf{N}$ & $\begin{array}{l}\text { Not } \\
\text { Ind. }\end{array}$ & $\mathbf{N}$ \\
\hline Brooke & 0.3250 & 1 & -- & 0 & -- & 0 & -- & 0 & -- & 0 & 0.3809 & 196 \\
\hline Cabell & 0.3629 & 539 & 0.3492 & 16 & 0.2237 & 9 & -- & 0 & -- & 0 & 0.3585 & 210 \\
\hline Harrison & 0.5481 & 5 & -- & 0 & -- & 0 & -- & 0 & -- & 0 & 0.5000 & 4 \\
\hline Marion & 0.3492 & 57 & -- & 0 & 0.2163 & 1 & -- & 0 & 0.3286 & 1 & 0.3306 & 280 \\
\hline Monongalia & 0.3117 & 102 & -- & 0 & -- & 0 & -- & 0 & -- & 0 & 0.3050 & 257 \\
\hline Pleasants & -- & 0 & -- & 0 & -- & 0 & -- & 0 & 0.2471 & 3 & 0.3377 & 25 \\
\hline Taylor & 0.4814 & 24 & -- & 0 & 0.0494 & 2 & 0.5835 & 12 & 0.3764 & 16 & 0.3637 & 21 \\
\hline Tucker & -- & 0 & -- & 0 & -- & 0 & -- & 0 & 0.2204 & 4 & 0.2667 & 36 \\
\hline 8 Counties & 0.3566 & 729 & 0.2341 & 17 & 0.2190 & 13 & 0.5835 & 12 & 0.3005 & 242 & 0.3337 & 6,299 \\
\hline
\end{tabular}


TABLE 12. Average Assessment to Consideration Ratios for the Three West Virginia Studies

\begin{tabular}{|c|c|c|c|c|c|c|c|c|}
\hline \multirow[b]{2}{*}{ County } & \multicolumn{2}{|c|}{$\begin{array}{c}\text { Armentrout- } \\
\text { Haygood Study } 1 \\
\end{array}$} & \multicolumn{2}{|c|}{$\begin{array}{c}\text { Colyer-Templeton } \\
\text { Pre-sale (1968) } \\
\end{array}$} & \multicolumn{2}{|c|}{$\begin{array}{c}\text { Colyer-Templeton } \\
\text { Post-sale (1969) } \\
\end{array}$} & \multicolumn{2}{|c|}{$\begin{array}{l}\text { Current } \\
\text { Study }^{2} \\
\end{array}$} \\
\hline & Ratio & $\mathbf{N}$ & Ratio & $\mathbf{N}$ & Ratio & $\mathbf{N}$ & Ratio & $\mathbf{N}$ \\
\hline Barbour & 0.336 & 215 & 0.499 & 289 & 0.573 & 289 & 0.350 & 74 \\
\hline Berkeley & 0.288 & 433 & 0.297 & 716 & 0.374 & 716 & 0.324 & 106 \\
\hline Boone & -- & -- & 0.502 & 361 & 0.483 & 361 & 0.298 & 99 \\
\hline Braxton & -- & -- & 0.396 & 163 & 0.420 & 163 & 0.351 & 96 \\
\hline Brooke & 0.331 & 444 & 0.369 & 426 & 0.499 & 426 & 0.381 & 197 \\
\hline Cabell & 0.313 & 2,238 & 0.386 & 2,027 & 0.441 & 2,027 & 0.360 & 775 \\
\hline Calhoun & 0.348 & 103 & 0.516 & 111 & 0.539 & 111 & 0.334 & 46 \\
\hline Clay & 0.306 & 183 & 0.405 & 112 & 0.619 & 112 & 0.413 & 72 \\
\hline Doddridge & 0.588 & 106 & 0.383 & 110 & 0.407 & 180 & 0.250 & 92 \\
\hline Fayette & 0.207 & 777 & 0.517 & 848 & 0.508 & 848 & 0.293 & 99 \\
\hline Gilmer & 0.300 & 142 & 0.508 & 164 & 0.578 & 164 & 0.259 & 140 \\
\hline Grant & 0.318 & 143 & 0.257 & 224 & 0.342 & 224 & 0.243 & 69 \\
\hline Greenbrier & 0.206 & 606 & 0.394 & 829 & 0.401 & 829 & -- & -- \\
\hline Hampshire & 0.486 & 190 & 0.388 & 417 & 0.549 & 417 & 0.164 & 25 \\
\hline Hancock & 0.265 & 670 & 0.358 & 423 & 0.341 & 423 & 0.391 & 163 \\
\hline Hardy & 0.475 & 89 & 0.263 & 221 & 0.360 & 221 & 0.198 & 74 \\
\hline Harrison & 0.411 & 996 & 0.432 & 940 & 0.744 & 940 & 0.531 & 9 \\
\hline Jackson & 0.217 & 184 & 0.758 & 441 & 0.469 & 441 & 0.364 & 142 \\
\hline Jefferson & 0.365 & 162 & 0.338 & 881 & 0.437 & 881 & 0.254 & 102 \\
\hline Kanawha & 0.253 & 3,450 & 0.426 & 4,283 & 0.459 & 4,283 & -- & -- \\
\hline Lewis & 0.376 & 230 & 0.364 & 230 & 0.406 & 230 & -- & -- \\
\hline Lincoln & 0.251 & 134 & 0.366 & 329 & 0.436 & 329 & -- & -- \\
\hline Logan & -- & -- & 0.318 & 529 & 0.434 & 529 & 0.248 & 42 \\
\hline McDowell & 0.347 & 524 & 0.544 & 632 & 0.668 & 632 & 0.394 & 29 \\
\hline Marion & -- & -- & 0.336 & 522 & 0.427 & 522 & 0.336 & 339 \\
\hline
\end{tabular}




\begin{tabular}{lrrrrrrrr} 
Marshall & 0.375 & 439 & 0.333 & 494 & 0.528 & 494 & 0.312 & 176 \\
Mason & 0.266 & 400 & 0.349 & 537 & 0.376 & 537 & 0.324 & 8 \\
Mercer & 0.292 & 667 & 0.430 & 1,108 & 0.521 & 1,108 & 0.322 & 181 \\
Mineral & 0.428 & 381 & 0.374 & 511 & 0.444 & 511 & 0.333 & 158 \\
Mingo & -- & -- & 0.576 & 518 & 0.604 & 518 & 0.253 & 118 \\
Monongalia & 0.328 & 792 & 0.334 & 765 & 0.485 & 765 & 0.305 & 371 \\
Monroe & 0.387 & 128 & 0.349 & 385 & 0.482 & 385 & 0.237 & 55 \\
Morgan & 0.410 & 126 & 0.358 & 574 & 0.423 & 574 & 0.323 & 70 \\
Nicholas & 0.304 & 428 & 0.454 & 196 & 0.536 & 196 & 0.352 & 98 \\
Ohio & 0.435 & 995 & 0.456 & 902 & 0.536 & 902 & 0.410 & 390 \\
Pendleton & 0.354 & 110 & 0.240 & 148 & 0.388 & 148 & 0.103 & 35 \\
Pleasants & 0.357 & 122 & 0.498 & 201 & 0.467 & 201 & 0.327 & 28 \\
Pocahontas & 0.420 & 124 & 0.313 & 194 & 0.324 & 194 & 0.329 & 26 \\
Preston & 0.587 & 457 & 0.353 & 276 & 0.438 & 276 & 0.241 & 138 \\
Putnam & 0.309 & 265 & 0.250 & 869 & 0.362 & 869 & 0.284 & 199 \\
Raleigh & 0.255 & 1,363 & 0.286 & 1,183 & 0.501 & 1,183 & 0.299 & 86 \\
Randolph & 0.299 & 336 & 0.346 & 334 & 0.364 & 334 & 0.341 & 50 \\
Ritchie & 0.462 & 144 & 0.444 & 264 & 0.454 & 264 & 0.336 & 142 \\
Roane & 0.344 & 239 & 0.433 & 350 & 0.487 & 350 & 0.356 & 157 \\
Summers & -- & -- & 0.442 & 235 & 0.471 & 235 & 0.305 & 260 \\
Taylor & 0.425 & 212 & 0.449 & 155 & 0.547 & 155 & 0.418 & 68 \\
Tucker & 0.688 & 88 & 0.370 & 167 & 0.421 & 167 & 0.263 & 39 \\
Tyler & 0.440 & 135 & 0.514 & 260 & 0.558 & 260 & 0.303 & 20 \\
Upshur & 0.329 & 384 & 0.449 & 397 & 0.427 & 397 & 0.320 & 147 \\
Wayne & 0.265 & 568 & 0.335 & 835 & 0.369 & 835 & 0.265 & 91 \\
Webster & 0.314 & 246 & 0.402 & 175 & 0.541 & 175 & 0.425 & 91 \\
Wetzel & 0.274 & 378 & 0.467 & 481 & 0.556 & 481 & 0.375 & 157 \\
Wirt & -- & -- & 0.446 & 97 & 0.457 & 97 & -- & -- \\
Wood & 0.322 & 1,442 & 0.415 & 2,192 & 0.457 & 2,192 & 0.358 & 897 \\
Wyoming & 0.165 & 292 & 0.262 & 519 & 0.382 & 519 & 0.283 & 170 \\
State Totals & 0.314 & 23,280 & 0.402 & 31,920 & 0.465 & 31,950 & 0.336 & 7,313 \\
\hline 1 & & & & & & & &
\end{tabular}

\footnotetext{
${ }^{1} 48$ Counties, ${ }^{2} 50$ Counties
} 
limits were designated as "farms" although there was no certain way to determine if all actually were farms; (4) unimproved lots within corporate limits; (5) improved lots within corporate limits; (6) business property within corporate limits; and (7) all other property outside of corporate limits.

The study omitted many transactions even though they occurred in the selected years. The major criterion for inclusion was an indication of a sale price of the property, either the recital of the sale price in the deed, or the presence of documentary revenue stamps. Among the other types of transactions omitted from the study were sales by the Commissioner of Delinquent Lands; sales of cemetery lots; transfers involving only timber or mineral rights; conveyances between members of the same family wherein other than monetary consideration was involved; conveyances of partial interests; transfers in settlement of estates; and transfers by will.

The assessed valuation for the year following the year of the sale was used except for those cases where improvements were added to the property between the time of sale and the time of valuation by the assessor. In such cases the assessed valuation for the year of sale was obtained rather than for the following year, or in other words, the assessment was for the property as sold and not as later improved.

The study included data on 23,280 properties sold in 48 counties for a total of $\$ 97,122,487$, with an assessed value of $\$ 30,464,291$ and an assessment ratio of 0.3137. A large amount of variation existed both within and between counties. For all properties within the study, 10.3 per cent were assessed at less than 10 per cent of their sales values, 22.6 per cent were assessed at from 10 to less than 20 per cent of their sales values, and 5.4 per cent were assessed at 90 per cent or more of their sales values. More than half (54.7 per cent) of the properties were assessed at less than 30 per cent of their sales values and 18.5 per cent at 50 per cent or more. It was also indicated that unimproved lots outside corporate limits were assessed on an average at only 18.2 per cent of their sales price, whereas "farms" were assessed at 40.8 per cent. The assessment sales value ratio tended to decline as consideration increased.

\section{Colyer-Templeton Study}

The Colyer-Templeton study examined the treatment of real estate for assessment within and between the various counties of the state for the period of July 1,1968 , to June 30,1969 . This was done on a county-by-county basis and nearly 32,000 transfers were involved. Along with transfer information such as location, size, and consideration, data on tax assessments during the periods both before and after the transfers were collected from public records in the county courthouses.

In the 1968-69 period, the county average pre-sale assessment to consideration ratios averaged 0.3916 but varied for individual counties from a low of 0.24 to a high of over 0.75 , while the post-sales ratios averaged 0.4580 and ranged from 0.32 to 0.66 . Assessment to consideration ratios declined 
between 1968 and 1969 in six counties and increased in the other 49 . Examination of both the before and after sale ratios showed increases in the average ratio for the year following the sales. A majority of the county assessors, however, do not routinely reassess properties that are transferred unless there is parcelization or changes in improvements.

The assessment ratios tended to decline as the level of consideration increased. This meant that higher valued properties are assessed relatively less than low valued properties. Unimproved lots were, in nearly every county, assessed at a much lower value relative to their sales prices than any other type of property. In addition, very small acreages were assessed at higher ratios than were larger properties. In general, the assessment ratios were larger for properties with improvements and properties within corporate limits tended to be assessed relatively higher than rural land although this varied from county to county. 
[Blank Page in Original Bulletin] 


\section{APPENDIX \\ Chi-Square Analysis}

Chi-square analyses were run for the variables to see if there were statistically significant effects on the distribution of the assessment-sales value ratios. Chi-square analysis deals with the deviations of the observed numbers from expected observations or those specified by the hypothesis. Each deviation is squared, each square is divided by the hypothetical or expected number, and the results are added. The expected numbers appear in the denominators in order to introduce sample size into the quantity; it is the relative size that is important. Chi-square is given by the formula:

$$
\begin{aligned}
X^{2}=\Sigma(0-E)^{2} / E, \quad \text { where } \quad & X^{2}=\text { computed chi-square values } \\
& 0=\text { observed values } \\
& \mathrm{E}=\text { expected values }
\end{aligned}
$$

A chi-square analysis was made for the distributions of the assessment ratios with each of the classification variables plus counties and the distributions of acreages and consideration. Expected values were determined by the percentage in each category for all 50 counties. The results of the analysis are as follows:

\begin{tabular}{lccc} 
Variables & Chi-square & $\begin{array}{c}\text { Significance } \\
\text { Level }\end{array}$ & $\begin{array}{c}\text { Degrees of } \\
\text { Freedom }\end{array}$ \\
\hline Ratio and: & 1518.02 & under .001 & 40 \\
Consideration & 778.49 & under .001 & 40 \\
Acreage & 274.99 & under .001 & 50 \\
Zoning & 995.91 & under .001 & 80 \\
Present use & 289.10 & under .001 & 80 \\
Best use & 650.48 & under .001 & 30 \\
Class & 654.11 & under .001 & 30 \\
Location & 900.76 & under .001 & 20 \\
Improvements & & & \\
\hline
\end{tabular}


APPENDIX TABLE I. Expected and Actual Distributions of Acreage and Ratio Classes Based on State Totals for the Assessment to Consideration Ratio

\begin{tabular}{|c|c|c|c|c|c|c|c|c|c|c|c|c|}
\hline \multirow[b]{2}{*}{$\begin{array}{l}\text { Acreage } \\
\text { Classes }\end{array}$} & & \multicolumn{11}{|c|}{ Class Ranges for Assessment to Sales Value Ratios } \\
\hline & & $\begin{array}{l}0 \\
.09\end{array}$ & $\begin{array}{l}0.1- \\
0.19\end{array}$ & $\begin{array}{l}0.2- \\
0.29\end{array}$ & $\begin{array}{l}0.3- \\
0.39\end{array}$ & $\begin{array}{l}0.4 \\
0.49\end{array}$ & $\begin{array}{l}0.5- \\
0.59\end{array}$ & $\begin{array}{l}0.6- \\
0.69\end{array}$ & $\begin{array}{l}0.7- \\
0.79\end{array}$ & $\begin{array}{l}0.8- \\
0.89\end{array}$ & $\begin{array}{l}0.9- \\
0.99\end{array}$ & $\begin{array}{l}1 \text { and } \\
\text { Over }\end{array}$ \\
\hline $0.1-0.9$ & $\begin{array}{l}\text { E } \\
\text { A }\end{array}$ & $\begin{array}{l}57.5 \\
38\end{array}$ & $\begin{array}{l}77.7 \\
57\end{array}$ & $\begin{array}{l}113.7 \\
124\end{array}$ & $\begin{array}{c}77.1 \\
107\end{array}$ & $\begin{array}{l}50.6 \\
54\end{array}$ & $\begin{array}{l}32.3 \\
32\end{array}$ & $\begin{array}{c}11.9 \\
8\end{array}$ & $\begin{array}{l}10.6 \\
11\end{array}$ & $\begin{array}{l}4.6 \\
2\end{array}$ & $\begin{array}{l}4.8 \\
6\end{array}$ & $\begin{array}{l}18.3 \\
20\end{array}$ \\
\hline $1-4.9$ & $\begin{array}{l}\text { E } \\
\text { A }\end{array}$ & $\begin{array}{l}67.7 \\
58\end{array}$ & $\begin{array}{l}91.6 \\
84\end{array}$ & $\begin{array}{l}134.0 \\
133\end{array}$ & $\begin{array}{l}90.8 \\
99\end{array}$ & $\begin{array}{l}59.6 \\
56\end{array}$ & $\begin{array}{l}38.0 \\
47\end{array}$ & $\begin{array}{l}14.0 \\
15\end{array}$ & $\begin{array}{l}12.5 \\
12\end{array}$ & $\begin{array}{l}5.4 \\
7\end{array}$ & $\begin{array}{l}5.6 \\
8\end{array}$ & $\begin{array}{l}21.6 \\
22\end{array}$ \\
\hline $5-24.9$ & $\begin{array}{l}\text { E } \\
\text { A }\end{array}$ & $\begin{array}{l}48.2 \\
70\end{array}$ & $\begin{array}{l}65.2 \\
61\end{array}$ & $\begin{array}{l}95.4 \\
90\end{array}$ & $\begin{array}{l}64.6 \\
50\end{array}$ & $\begin{array}{l}42.4 \\
45\end{array}$ & $\begin{array}{l}27.1 \\
21\end{array}$ & $\begin{array}{l}10.0 \\
14\end{array}$ & $\begin{array}{c}8.9 \\
12\end{array}$ & $\begin{array}{l}3.8 \\
1\end{array}$ & $\begin{array}{l}4.0 \\
5\end{array}$ & $\begin{array}{l}15.4 \\
16\end{array}$ \\
\hline 25-99.9 & $\begin{array}{l}\text { E } \\
\text { A }\end{array}$ & $\begin{array}{l}72.0 \\
71\end{array}$ & $\begin{array}{c}97.3 \\
123\end{array}$ & $\begin{array}{l}142.4 \\
138\end{array}$ & $\begin{array}{l}96.5 \\
77\end{array}$ & $\begin{array}{l}63.4 \\
62\end{array}$ & $\begin{array}{l}40.4 \\
41\end{array}$ & $\begin{array}{l}14.9 \\
17\end{array}$ & $\begin{array}{l}13.3 \\
12\end{array}$ & $\begin{array}{l}5.7 \\
9\end{array}$ & $\begin{array}{l}6.0 \\
4\end{array}$ & $\begin{array}{l}23.0 \\
21\end{array}$ \\
\hline $100++$ & $\begin{array}{l}\mathbf{E} \\
\mathbf{A}\end{array}$ & $\begin{array}{l}30.6 \\
39\end{array}$ & $\begin{array}{l}41.3 \\
48\end{array}$ & $\begin{array}{l}60.4 \\
61\end{array}$ & $\begin{array}{l}41.0 \\
37\end{array}$ & $\begin{array}{l}26.9 \\
26\end{array}$ & $\begin{array}{l}17.2 \\
14\end{array}$ & $\begin{array}{l}6.3 \\
3\end{array}$ & $\begin{array}{l}5.6 \\
4\end{array}$ & $\begin{array}{l}2.4 \\
3\end{array}$ & $\begin{array}{l}2.5 \\
0\end{array}$ & $\begin{array}{l}9.7 \\
9\end{array}$ \\
\hline
\end{tabular}

E Rows are expected numbers and A Rows are actual numbers of observations.

Chi Square $=78.487$ which is statistically significant at under .001 with 40 degrees of freedom. 
[Blank Page in Original Bulletin] 